\title{
Samatähenduslike sünteetiliste ja analüütiliste verbide kasutamine
}

\author{
PILLE ESLON, HELERIIN PAEOJA \\ Tallinna Ülikool
}

Ülevaade. Huvi samatähenduslike sünteetiliste ja analüütiliste verbide vastu tekkis artikli esimesel autoril vene-eesti-vene tõlkesõnastikke toimetades, kui silma hakkasid regulaarsed valikud vene verbi grammatilise aspekti ning eesti keele sünteetiliste ja analüütiliste verbide vahel. Kuigi tegu on raskesti märgatava ja sugugi mitte sagedase nähtusega, tekitab see küsimusi: millal eelistab emakeelekõneleja kasutada sünteetilist, millal analüütilist verbi; kas lisaks samatähenduslikkusele ja vormilisele lihtsusele (sünteetiline verb koosneb ühest komponendist) või keerukusele (analüütiline verb vähemalt kahest komponendist) on veel tunnuseid, mis sünteetilise ja analüütilise verbi valikuid piiravad. Käesoleva uurimuse eesmärk on leida nendele küsimustele vastuseid.

Analüüsitakse viit samatähendusliku sünteetilise ja analüütilise verbi paari (igatsema - igatsust tundma, lahkuma - ära minema, nõustuma - nõus olema, muretsema - muret tundma, töötama - tööd tegema), otsitakse mõlema verbi kasutusele omaseid keelestruktuure, analüüsitakse nende leksikaalsemantilise ja morfosüntaktilise varieerumise piire, võrreldakse verbide tähendusi. Nende tunnuste põhjal saab teha mõningaid järeldusi selle kohta, kas tegu võiks olla ühe verbi kahe vormiga või kahe erineva verbiga.

Uurimuse empiiriline aspekt on seotud hüpoteesiga semantiliselt lähedaste sünteetiliste ja analüütiliste verbide tõmbumisest, millega kaasnevad ühelt poolt struktuursed, morfoloogilised, morfosüntaktilised ja leksikaalsemantilised kasutuspiirangud ning teisalt vaba varieerumine. Sisuliselt vastandlikud tendentsid - kinnistumine ja varieerumine - toimivad keele leksikaal- 
grammatilises perifeerias sama eesmärgi nimel, tagades keele pideva uuenemise ja säilimise.

Võtmesõnad: sünteetilised ja analüütilised verbid; kasutusgrammatika; morfosüntaktilised mustrid; leksikaalsemantiline ja grammatiline varieerumine; klasteranalüüs; n-grammid; eesti keel

\section{Uurimisküsimuse kujunemine}

Vene-eesti ja eesti-vene tõlkesõnastike toimetamine (TEA 2001; TEA 2005; TEA 2007; TEA 2010) tõi esile keerukohti tüpoloogiliselt erinevate keelte sõnavara kirjeldamisel, eriti seoses verbidega. Neil raskustel on kindlad grammatikast ja semantikast tulenevad põhjused, mida pole eriti uuritud.

Kuna verb on lause predikatiivne tuum ja verbi rektsioonistruktuur lause argumendistruktuuri alus, siis tekkis artikli esimesel autoril mõte koostada vene-eesti verbisõnastik ning analüüsida lähemalt regulaarseid keeltevahelisi leksikaalsemantilisi ja grammatilisi seoseid. Venekeelne algmaterjal pärineb vene-saksa verbi-noomeniühendite sõnastikust (Demidova jt 1986), kust valiti välja tuhat verbi koos rektsioonistruktuuri ja näidetega. Valdava osa vene verbidest moodustavad aspektipaarid, milles verb on imperfektiivse ja perfektiivse aspekti vormides. $60 \%$ neist aspektipaaridest on sufiksaalset päritolu (спрашивать/ cnросить * 'küsima', вспоминать/вспомнить * 'meenutama', 'meelde tuletama') ja $38 \%$ prefiksaalsed (мстить/отомстить ${ }^{*}$ 'tasuma', 'kätte maksma'). 2\% moodustavad üheaspektilised imperfectiva tantum (знать 'teadma', 'tundma'; 'oskama'), harvem perfectiva tantum verbid (помнить * 'mäletama', 'meeles pidama') ning üksikud kaheaspektilised verbid (исследовать 'uurima', велеть 'käskima').

Selgus, et sufiksaalset päritolu vene aspektipaaride sagedamad eestikeelsed tõlkevasted on erineva tähendusega sünteetilised verbid (обращать/обратить 'pöörama', 'suunama'; 'muutma'; 'sundima'), järgnevad erineva tähendusega sünteetilised ja analüütilised verbid (перебивать/nеребить * ära lõhkuma'; 'katkestama'), harvem üks sün- 
teetiline verb (спрашивать/спросить * 'küsima'), mõned erineva tähendusega analüütilised verbid (переносить/перенести* 'edasi lükkama', 'üle viima'; 'läbi põdema'; 'üle elama') ning samatähenduslikud sünteetilised ja analüütilised verbid (вспоминать/вспомнить* 'meenutama', 'meelde tuletama', возращать/возвратить ' tagastama', 'tagasi andma'), mis moodustavad paari (meenutama - meelde tuletama, tagastama tagasi andma).

Kirjeldatud skeem kordub vene prefiksaalset päritolu aspektipaaride eestikeelsetes tõlkevastetes. Vahe on vaid selles, et sagedamad on erineva tähendusega sünteetilised ja analüütilised verbid (звонить/позвонить 'helistama, 'kella andma'; 'kella lööma'), järgnevad erineva tähendusega sünteetilised verbid (делать/сделать 'tegema', 'valmistama'; 'mõõtma'; 'proovima'; 'muutma'), üks analüütiline või mitu erineva tähendusega analüütilist verbi (завтракать/позавтракать ${ }^{*}$ 'hommikueinet sööma') ning samatähenduslikud sünteetiline ja analüütiline verb (мстить/отомстить * 'tasuma', 'kätte maksma', влиять/повлиять 'mõjutama', 'mõju avaldama'), mis moodustavad paari (tasuma - kätte maksma, mõjutama - mõju avaldama).

Vene keele imperfectiva (harva perfectiva) tantum ning kaheaspektiliste verbide eestikeelseks tõlkevasteks on tavaliselt üks sünteetiline verb (велеть käskima'), harvem erineva tähendusega sünteetilised verbid (иметься 'olema'; 'omama'), erineva tähendusega sünteetilised ja analüütilised verbid (бyдumb 'äratama'; 'ergutama', 'ärgitama'; 'tekitama', 'esile kutsuma') või üks analüütiline verb (предвидеть 'ette nägema', полюбить ` 'armastama hakkama'). Loendist ei puudu ka samatähenduslike sünteetiliste ja analüütiliste verbide paarid, nagu huvitama - huvi pakkuma (интересовать 'huvitama', 'huvi pakkuma'), valmistuma - ettevalmistusi tegema (готовиться 'valmistuma', 'ettevalmistusi tegema'), soojendama - soojaks tegema ( zpems 'soojendama', 'soojaks tegema'). ${ }^{1}$

Tegu on vene-eesti verbi-noomeniühendite sõnastikus esile tulnud regulaarsete tõlkevastetega: sufiksaalse aspektipaari puhul on sagedamad

1 Põhjalikum vene-eesti verbe iseloomustavate korrelatsioonide kirjeldus vt Eslon 2004: 103-122. 
erineva tähendusega sünteetilised verbid; prefiksaalse aspektipaari puhul erineva tähendusega sünteetilised ja analüütilised verbid; ühe- ja kaheaspektiliste verbide puhul üks sünteetiline verb. Neis kolmes rühmas kõige harvem esinenud tõlkevasted on samatähenduslikud sünteetilised ja analüütilised verbid, mis moodustavad paare, nagu tagastama - tagasi andma, mõjuma - mõju avaldama, huvitama - huvi pakkuma, valmistuma - ettevalmistusi tegema. Vene-eesti verbi-noomeniühendite sõnastiku tuhande verbi tõlkevastetest moodustavad sarnased juhtumid vaid $4 \%$ ehk kokku kakskümmend paari, kus sünteetilist ja analüütilist verbi ühendab sama tähendus.

Kuigi tegu on üsna marginaalse nähtusega, tekitab selle regulaarsus tõlkevastetes küsimusi: millal eelistab emakeelekõneleja sünteetilist, millal analüütilist verbi; mis iseloomustab nende tekstikasutust; millised tunnused eristavad samatähenduslikke verbe. Käesoleva uurimuse eesmärk on leida nendele küsimustele vastuseid.

Selleks valisime vene-eesti verbi-noomeniühendite tõlkesõnastikust viis sünteetilise ja analüütilise verbi paari (igatsema - igatsust tundma, lahkuma - ära minema, nõustuma - nõus olema, muretsema - muret tundma, töötama - tööd tegema), millel on sarnane rektsioon, ning analüüsisime nende tekstikasutust. Saadud tulemustel on nii teoreetilisempiiriline kui ka rakenduslik väärtus.

Teoreetilis-empiiriline aspekt on seotud hüpoteesiga semantiliselt lähedaste sünteetiliste ja analüütiliste verbide tõmbumisest verbipaarideks, kus sünteetilist verbi eristavaks tunnuseks on tähistatava tegevuse abstraktsus ja analüütilisel verbil tegevuse konkreetsus. Mõlemal juhul kaasnevad sellega struktuursed, morfoloogilised, morfosüntaktilised ja leksikaalsemantilised kasutuspiirangud. Rakenduslik aspekt on seotud keeleõppe, tõlkimise, teksti automaatanalüüsi ja automaattõlke arendamisega.

Analüüsi aluseks võtsime Tartu Ülikooli 1990-ndate aastate eesti ilukirjanduskeele alamkorpuse tekstid, ${ }^{2}$ kuna need on hoolikalt läbi mõeldud sõnastusega ning järeltoimetatud. Artikli autorite varasemates

2 Vt www.cl.ut.ee/korpused/segakorpus/eesti_ilukirjandus_1990/ (11.1.2015). 
uurimustes on analüüsitud samatähenduslike sünteetiliste ja analüütiliste verbide aspektuaalset semantikat (Eslon 2004; 2005), võrreldud nende tähendust, rektsioonistruktuure ning kasutussagedust 1890-ndate ja 1990-ndate eesti ajakirjanduskeeles (Paeoja 2011; 2012), sünteetiliste ja analüütiliste verbide kasutusmustreid 1990-ndate eesti ilukirjanduskeeles (Paeoja 2015). Verbi tähendusvälja kirjeldamisel oleme tuginenud eesti keele seletavale sõnaraamatule (EKSS).

\section{Analüüsi etapid ja meetodid}

1990-ndate aastate eesti ilukirjanduskeele korpuse maht on ligi 5,8 miljonit sõnet. Sõnatüvede, laadivahetuslike sõnade puhul ka konkreetsete grammatiliste vormide järgi leidsime korpusest laused, milles on kasutatud verbe igatsema - igatsust tundma, lahkuma - ära minema, nõustuma - nõus olema, muretsema - muret tundma, töötama - tööd tegema, kokku 4685 lauset. Sellest valimist jätsime välja laused, mis valitud verbe ei sisaldanud (valdavalt vormihomonüümia juhtumid).

Järgnevalt leidsime valimi tekstikasutusmustrid. Selleks rakendasime programmi Klastrileidja ${ }^{3}$, mis töötab andmekaeve põhimõttel: otsib morfosüntaktiliselt analüüsitud tekstist sarnaseid morfo- ja süntaksimärgendite lineaarseid järjendeid, ühendab need järgemööda, leiab sedasi tekstikasutusmustrid, fikseerib nende sageduse ja eraldab ainukordsetest. Enne tekstivalimi sisestamist Klastrileidjasse tuleb uurijal valida n-grammi pikkus (bigramm, trigramm, tetragramm jne), määrata analüüsi lingvistiline objekt - morfoloogia, süntaks või morfosüntaks -, ning otsustada, kas arvestada Z-märgendiga (tähistab kirjavahemärki).

Samatähenduslike sünteetiliste ja analüütiliste verbide kasutusmustrite leidmiseks valisime trigrammid. Vaatluse all on verbist kaks üksust vasakule ja kaks üksust paremale jääv kontekst, millest tulenevad ka artiklis kasutatud mõisted verbialguline ning verbilõpuline struktuur, morfoloogiline klass, alamklass, klaster ja trigramm. Kuna tegu on verbi

3 Lingvistilise klasteranalüüs programm, autor Sander Ots (2012). Veebiliidest saab kasutada aadressil http://evkk.tlu.ee/Search/search_reeglid.html (12.2.2015). 
lähiümbruse mustrite otsimisega, siis polnud vajadust Z-märgendit arvestada. Lingvistiliseks objektiks valisime morfosüntaksi, sest meie eesmärk on leida samatähenduslike sünteetiliste ja analüütiliste verbide tekstikasutust iseloomustavate struktuuride morfosüntaktilisi ja leksikaalsemantilisi piiranguid ning vaba varieerumist. Trigrammide struktuuri aluseks on sõnaliigimärgendite järjendid, klastrid tulevad esile morfo- ja süntaksimärgendite alusel. Nende hulka saab arvuliselt fikseerida. Trigrammide leksikaalsemantilised piirangud on seotud trigrammides kasutatud lekseemidega, mille valik pole juhuslik, vaid sõltub trigrammi morfosüntaksist. See võimaldab kirjeldada keele leksikaalgrammatilises perifeerias semantika ja grammatika piirimail toimivaid protsesse.

Pärast n-grammi pikkuse ja lingvistilise objekti määramist väljastas programm Excelis 47155 trigrammi, mille hulgast valisime välja 5217: igatsema (kokku 417), igatsust tundma (43), lahkuma (1543), ära minema (452), töötama (1291), tööd tegema (310), muretsema (663), muret tundma (25), nõustuma (345), nõus olema (128). Järgnevalt reastasime iga verbi trigrammid verbialgulisteks ja verbilõpulisteks trigrammideks ning leidsime verbist vasakule ja paremale jäävad tekstikasutusmustrid koos nende esinemissagedusega.

Klasteranalüüsi tulemusi kirjeldame trigrammide sageduse alusel klastrites ja klastrite hulga järgi alamklassides. Arvandmete alusel tuleb esile morfosüntaktiliste trigrammide ja morfoloogiliste klastrite hierarhia morfoloogilistes alamklassides. Analüüsime artiklis põhjalikumalt vaid suurema osakaaluga klastreid, mis sisaldavad kokku 3146 trigrammi, ebaolulisi ja marginaalseid klastreid me ei arvesta.

Seejärel interpreteerime kvantitatiivse analüüsi tulemusi lingvistiliselt. Aluseks on trigrammide-klastrite-alamklasside hierarhia, mille tipus on kaks morfoloogilist klassi: verbialguline ja verbilõpuline. Alamklassid tulevad esile mustritena verbile järgneva ja eelneva komponendi alusel, kus vastavalt klassile varieerub morfoloogiliselt kas esimese ja keskmise või keskmise ja viimase komponendi sõnaliik, nt verbilõpuline alamklass adverb-verb ehk -DV või verbialguline alamklass 
verb-substantiiv ehk VS-. ${ }^{4}$ Alamklassides eristuvad morfoloogilised klastrid (nt adverb-adverb-verb ehk DDV-struktuur), milles kahe komponendi kokkulangemise ja kolmanda komponendi sõnaliigi varieerumise alusel moodustub üks või mitu mustrit. Iga klastri trigrammide morfosüntaktiline varieerumine põhineb morfo- ja süntaksimärgenditel. Näiteks ühe ja sama morfoloogilise VSS-struktuuri trigrammide morfosüntaks võib varieeruda: 1) öeldisverb indikatiivis imperfekti ainsuse 3. pöördes + substantiiv ainsuse nominatiivis subjektina + substantiiv ainsuse partitiivis objektina (nõustus professor pead <vangutades $>$ ); 2) öeldisverb pluskvamperfekti liitajavormina + substantiiv ainsuse genitiivis nimisõna eestäiendina + substantiiv ainsuse komitatiivis adverbiaalina (<ta oli $>$ nõustunud Agrippa plaaniga). Varieeruvad verbi grammatilised vormid (esimeses näites imperfekti ainsuse 3. pööre, teises pluskvamperfekti ainsuse 3. pööre) ja substantiivide vormid ning funktsioonid (esimeses näites ainsuse nominatiiv subjektina + ainsuse partitiiv objektina, teises näites ainsuse genitiiv eestäiendina + ainsuse komitatiiv adverbiaalina). Lisaks varieerub VSS-struktuur ka leksikaalsemantiliselt. Nt verbiga nõustuma ('nõusse jääma') tähistab VSS-struktuuri viimane substantiiv kehaosa, asja, olendit või abstraktset mõistet (huuled, pea; salakaup; Andreas, töökaaslane; innukus, pahandus) ning sellele eelnenud substantiiv alati olendit (Jaan, Sergei, vend, seersant). Näidete põhjal tuleb esile seos trigrammi struktuuri, lekseemide semantika ja komponentide morfosüntaktilise varieerumise vahel.

Käesolevas artiklis tugineme verbide kasutusmustreid lingvistiliselt analüüsides sagedamatele vormi- ja lekseemikooslustele, mis iseloomustavad konkreetset struktuuri, selle morfoloogilist, morfosüntaktilist ja leksikaalsemantilist varieerumist. Püüame seletada, kas samatähenduslikud sünteetilised ja analüütilised verbid moodustavad paari, mille liikmed erinevad vaid vastandtunnuse abstraktne/konkreetne poolest või on ka muid eristavaid tunnuseid. Vastuse leidmisel on aluseks koosmõju, mis iseloomustab iga verbi kasutusele omaseid struktuurseid, morfoloogilisi, morfosüntaktilisi ja leksikaalsemantilisi valikuid. Selle

\footnotetext{
4 Sõnaliigilühendite seletused vt artikli lõpus.
} 
põhjal peaks kujunema selgem ettekujutus, mille poolest tähenduselt lähedaste sünteetiliste ja analüütiliste verbide kasutustingimused sarnanevad või erinevad. Nii lisandub uusi teadmisi selle kohta, mis toimub keelesüsteemi leksikaalgrammatilises perifeerias.

\section{Kasutuspõhisus ja keele muutumine}

Käesolev uurimus ei tugine ühelegi spetsiaalsele teooriale, kuid on seotud kasutuspõhistes uurimustes ja keelemuutuste käsitlustes esitatud küsimustega.

Seos kasutuspõhisusega tuleneb eelkõige uurimismeetodist, milleks on valitud korpuspõhine andmekaeve põhimõttel rajanev kvantitatiivne tekstianalüüs, mis toob esile, kuidas emakeelekõneleja keelevahendeid valib ja kombineerib (meetodi kasutamisest vt Eslon 2012; 2014a; 2014b; Trainis \& Allkivi 2014; Paeoja 2015; Trainis 2015). Kirjeldades tekstikasutusmustreid, nende ilmnemise sagedust, morfosüntaktilise ja leksikaalsemantilise varieerumise piire, on võimalik leida samatähenduslikele sünteetilistele ja analüutilistele verbidele omaseid kasutuseelistusi ning kirjeldada neid lingvistiliselt.

Joseph Greenberg (1990: 219-220) on rõhutanud, et sageduse mõiste on keskne semantika ja grammatika vaheliste seoste esiletoomiseks. Joan Bybee ja Clay Beckneri (2010: 827) järgi on kasutussagedus keelesüsteemi arengu peamine liikumapanev jõud: mida rohkem mingit vormi või konstruktsiooni kasutatakse, seda tõenäolisem on, et selle struktuur muutub lühemaks, tähendus ähmastub ja juurde tuleb uusi grammatilisi funktsioone, mis avalduvad nii kirjalikus kui ka suulises tekstiloomes. Keelestruktuuri, mida kasutatakse piisavalt sageli, nimetatakse juurdunud või kinnistunud malliks (Croft \& Cruse 2004: 292). Niisugused kinnistunud mallid või mustrid aitavad seletada ja põhjendada keele kui süsteemi funktsioneerimise seaduspärasusi. Kindlat liiki juurdunud struktuurid on taustaks semantilistele muutustele ja funktsionaalsetele nihetele. Järelikult on tekstikasutusmustritel keele funktsionaalse potentsiaali avaldumises - seega ka keele uurimisel - olulisem roll, kui arvata võib. 
Kõikides keeltes leidub näiteid semantilise tuhmumise ja funktsioonide avardumise kohta. Nii on Bernd Heine ja Tania Kuteva võrrelnud inglise keele prepositsiooni in kasutamist kolmes lauses: 1) John died in London; 2) John died in Iraq ja 3) John died in a car accident. Kahes esimeses lauses on in keelenormi kohaselt ruumilise eessõna funktsioonis, kolmandas väljendab põhjuslikkust. Seega sõltub funktsioonide avardumine keelendi semantilisest hajususest, mis võimaldab keelendit kasutada erinevates kontekstides. Pikemas perspektiivis võivad nii välja kujuneda keelemuutused, nagu üleminek täistähenduslikust põhiverbist grammatilist infot edastavaks abiverbiks, nt He used all the Money ja He used to come on Tuesdays. (Heine \& Kuteva 2007: 37-38) Funktsiooni muutumisega kaasneb uus grammatiline tähendus, mis täistähenduslikul verbil puudus - used to tähistab minevikus harjumuspäraselt toimunud tegevust.

Traditsiooniliselt on morfoloogiat ja süntaksit peetud grammatilise korralduse kaheks erinevaks tasandiks, mida tuleb vaadelda lahus. Näiteks ütlevad Alexandra Aikhenvald ja Robert Dixon (2002: 6), et morfoloogia tegeleb sõnade "koostamisega" ning süntaks nende "ühendamisega”. Meie oleme samal seisukohal Martin Haspelmathiga: morfoloogia, süntaksi ja semantika vahel on tihe seos, mis seletab nende põimumist keelekasutuses. Kasutuspõhise käsitluse järgi koosneb loomulik keelekasutus elementide (vormid, lekseemid) ja struktuuride kombineerimise reeglitest, mis moodustavad palju komplekssema ja mitmekülgsema ainese keele olemuse mõistmiseks, seletamiseks ja kirjeldamiseks, kui seda on akadeemilised grammatikad ning traditsioonilised keeleteooriad. (Haspelmath 2010: 1, 6-7)

Meie uurimisobjektiks olevate samatähenduslike sünteetiliste ja analüütiliste verbide puhul tekitab küsimusi nende staatus, millele saame vastuseid kasutusmustreid lingvistiliselt kirjeldades. Sellest nähtub, kuidas verbiga tähistatava tegevuse semantika mõjutab struktuurilt erinevate trigrammide morfosüntaktilisi ja leksikaalsemantilisi valikuid. Esialgu saab väita vaid seda, et verbipaari mõlemat liiget võib üldjuhul kasutada samas kontekstis, kuid sünteetilise verbi asendamine 
analüütilisega ja vastupidi muudaks sõnajärge (inimesed haigestusid massiliselt ja inimesed jäid massiliselt haigeks) ning lausestust (ta haigestus grippi ja ${ }^{\star}$ ta jäi grippi haigeks ta jäi grippi). Ent kõrvuti nimetatud juhtumitega leidub ka hulgaliselt sünonüümse varieerumise näiteid, mis jätavad sõnajärje ja lausestuse muutmata, nt nad töötasid hommikuni ja nad tegid tööd hommikuni; lahkusid peolt esimestena ja läksid peolt ära esimestena; igatsevad tema järele ja tunnevad tema järele igatsust; nõustume sellega kindlasti ja oleme sellega kindlasti nõus. See tähendab, et sünteetilist ja analüütilist verbi eristavad tunnused on neutraliseerunud, nt tegevuse või sündmuse abstraktsus/konkreetsus, piiritlematus/piiritletus. Sünteetilise ja analüütilise verbi (nagu ka teksti) abstraktsuse astet saab interpreteerida, hinnates pikema tekstiosa või lause põhjal, kas mingit nähtust, sündmust, isikut, eset, tegevust jm on kirjeldatud abstraktse või konkreetsena (vt Muischnek \& Vider 2005: 108-111; Asser jt 2004). Niisugused hinnangud on subjektiivsed, piiratud teoreetilise raamistikuga, kuid samas ei teki need iseenesest, vaid on seotud kindlate tekstiliste struktuuridega. Selle taga on loogilised seosed, mille põhjal me mõisteid liigendame. Immanuel Kanti järgi saab mõistepaarideks ühendada abstraktsuse ja sünteetilisuse ning konkreetsuse ja analüütilisuse. Sünteetilisus tähistab ühte abstraktset, semantiliselt avarat substantsi, analüütilisuse puhul on aga tegu kahe erineva substantsiga, millest üks konkretiseerib teist. (Kant 1904: 36) Olgugi et Kant ei tegele antud juhul abstraktse ja konkreetse ning sünteetilise ja analüütilise vastandamise ja sidumisega, osutab see kujukalt neid mõisteid ühendavale sisule: mõiste mahult on abstraktsus ja sünteetilisus avaramad kui konkreetsus ja analüütilisus. Siit tuleneb kaks järeldust: 1) tunnuse abstraktne/konkreetne neutraliseerumine näitab samatähenduslike sünteetiliste ja analüütiliste verbide semantilist lähedust, 2) vastandus abstraktne/konkreetne pole relevantne tunnus eristamaks samatähenduslikke sünteetilisi ja analüütilisi verbe.

Sama kehtib ka tegevuse leksikaalgrammatilise piiritlematuse/piiritletuse suhtes, mida kasutatakse grammatikakirjeldustes. Üldjuhul tähistab sünteetiline verb piiritlemata tegevust ja seisundit, analüütiline 
piiritletud tegevust, mis on kõnemomendiks ammendunud või ammendub lähitulevikus, märgib millegi lõppu-algust jm (tülli minema = uue sündmuse algus, terveks saama = eelnenud seisundi lõpp ja uue seisundi algus, kahe sündmuse vaheldumine, soojaks tegema = sündmuse potentsiaalne ammendatus). (Vt Eslon 2005: 367) Samas leiab tekstikasutusest enamasti niisuguseid kontekste, kus selliseid verbe nagu tervenema ja terveks saama võib interpreteerida nii piiritlemata kui ka potentsiaalselt piiritletud tegevusena ( $k \ddot{u l l}$ ta aja jooksul terveneb/terveks saab), sest sünteetilise verbi semantika on analüütilise verbi semantikast avaram, sisaldab varjatult potentsiaalse piiri ideed ning analüütilise verbi tegevust saab tõlgendada piiritlematuna. Seega on verbi tegevuse piiritlematuse/ piiritletuse tunnus tuhmunud, mis soodustab sünteetilise ja analüütilise verbi sünonüümset varieerumist. Järelikult on nende verbide eristamisel vähe abi ka grammatikakirjeldustest.

Paremini töötab formaalne kriteerium, milleks on sünteetilise verbi struktuuriline lihtsus (koosneb ühest komponendist) ja analüütilise verbi keerukus (koosneb vähemalt kahest komponendist). Analoogselt tuleb käsitleda ka samatähenduslike sünteetiliste ja analüütiliste verbidega kinnistunud ja/või vabalt varieeruvaid struktuure, mis lingvistilises klasteranalüüsis mustritena esile tulevad. Neid struktuure on verbipaaride kaupa võimalik süstematiseerida, võrrelda, kõrvuti ühisjoontega tuua esile sünteetilist ning analüütilist verbi eristavaid leksikaalsemantilisi ja morfosüntaktilisi tunnuseid. Seejärel saab sõnastada reegleid, millest on abi keeleõppes, kakskeelsete sõnastike koostamises, samuti keeltevaheliste seoste empiirilises analüüsis.

Keelekasutaja tänased eelistused, mis automaatanalüüsi tulemusel mustritena esile tulevad, näitavad hetkel toimivaid universaalseid keelesiseseid ja keeltevahelisi arenguid või keeleomaseid ja kontaktidest tulenevaid protsesse (vt Haspelmath 1999; Aikhenvald \& Dixon 2002). Võõrmõjude rolli saab paremini hinnata tagasivaatavalt, sest tihtipeale kulgevad keeleomased sisemised protsessid paralleelselt võõrmõju(de)ga, nt soome keele aspektilise objekti saamislugu (Larjavaara 1991) või liivi keele käändeparadigma lühenemist kompenseerivad 
keelesisesed võimalused (Grünthal 2003). Samas on ka kirjeldatud juhtumeid, kui muutused kulgevad paralleelselt eri keeltes, mis üksteist ei mõjuta. Näiteks numeraali üks (saksa ein, vene oдuH, inglise one, soome $y k s i$ ) funktsioonid on ümber mõtestatud impersonaalsuspartiklina: siin oli üks mees, st 'keegi; pole teada, kes konkreetselt; abstraktne, määramata isik', - hier war ein Mann - здесь бьл один мужчина - here was one man - tässä oli yksi mies (vt ka Pajusalu 1999). Tegu on universaalse nähtusega, mis kulgeb paralleelselt eri keeltes.

Niisugused sõltumatult kulgevad ontoloogilised protsessid avalduvad tekstikasutuses. Loomuliku keele kasutusmustrite põhjal näeb mitte ainult seda, kuidas keele elemente kombineeritakse ja ümber mõtestatakse, vaid ka seda, millistel tingimustel keelendite funktsioonid avarduvad või kitsenevad. Avardumisega on seotud eristavate semantiliste ja grammatiliste tunnuste tuhmumine, neutraliseerumine või kadu, millest annab märku lekseemide-vormide varieerumine, asendamine ning kasutamine neile mitteomases kontekstis. Funktsioonide kitsenemine kinnistab teatud lekseemide ja vormide kasutuse kindlat liiki struktuuriga. ${ }^{5}$

Ka eesti keele samatähenduslike sünteetiliste ja analüütiliste verbide staatust võib analüüsida ja kirjeldada funktsioonide avardumise/ kitsenemise võtmes, mis on seotud kindlate sõnaliigijärjendite ehk struktuuridega. Seda seisukohta toetavad muud verbisüsteemis toimivad protsessid. Näiteks Natalia Vaiss on kirjeldanud nihkeid verbide leksikaalgrammatiliste rühmade vahel: partitiiv- ja perfektiivverbide tähendus tuhmub, neid kasutatakse järjest rohkem avaratähenduslike aspektverbidena ning see tendents on eesti keeles jõudsalt arenemas. Esile tuleb rühm mitme aspektuaalse tähendusega sünteetilisi verbe, mille puhul väiksemgi tähendusnüansi nihe kutsub esile muutusi rektsioonistruktuuris (Vaiss 2004: 65). Sünteetiliste verbide leksikaalne

5 Vt käänete sünkreetsust ehk ühe käände asendamist teisega (Grünthal 2010); probleemidest sõnaliigi määramisel ja semantilisel ühestamisel, mille puhul oleks kasu formaalsete tunnuste või kontekstireeglite kirjeldamisest (Muischnek \& Vider 2005: 107). 
aspektilisus tuhmub, verbi saab tõlgendada mitut moodi ja kasutada erinevaid aspektisituatsioone tähistavates kontekstides.

Sünteetiliste aspektverbide semantilisest hajususest tuleneb nende polüfunktsionaalsus, mis on eelduseks järgnevatele arengutele, k.a paaride moodustumine samatähenduslike analüütiliste verbidega. Ühelt poolt tulevad esile struktuurid, milles sünteetilise ja analüütilise verbi sünonüümne varieerumine on võimalik sõnajärge ja lausestust muutmata, teisalt on olemas rida juurdunud struktuure ning leksikaalselt ja morfosüntaktiliselt varieeruvaid mustreid, mis eristavad sünteetilise ja analüütilise verbi kasutust. Neis vastandlikes tendentsides kajastuvad kõikumised keele leksikaalgrammatilises perifeerias, keelesüsteemi kõige mobiilsemas osas. Siin toimivad protsessid on vajalikud ühelt poolt keele säilimiseks ja teisalt pidevaks uuenemiseks, sest kinnistumine fikseerib ja vaba varieerumine võimaldab loomingulist kasutamist. Need, sisult vastandlikud tendentsid tasakaalustavad teineteist, töötades sama eesmärgi nimel.

Kinnistumise ja vaba varieerumise dialektika seletab ka samatähenduslike sünteetiliste ja analüütiliste verbide tekstikasutust. Valikud rikastavad üldist keelelist varieerumist, pakkudes erinevaid väljendusvõimalusi, samas kui leksikaalsemantilised, morfosüntaktilised ja struktuursed piirangud neid omavahel eristavad. Vaba varieerumise ja kinnistumise näidete põhjal saab hakata vaatama, millal moodustavad samatähenduslikud sünteetilised ja analüütlised verbid paari kui iseseisva leksikaalse üksuse, millal on tegu semantiliselt lähedaste, ent siiski erinevate verbidega, mille kasutust iseloomustavad erinevad kinnistunud struktuurid.

\section{Analüüsi tulemused}

Peatüki esimeses osas anname ülevaate samatähenduslike sünteetiliste ja analüütiliste verbide kasutustendentsidest. Kirjeldame verbide esinemust üldvalimis (vt joonis 1), trigrammide hulka alamvalimites (vt tabel 1) ning osakaalu morfoloogilistes klassides ja alamklassides 


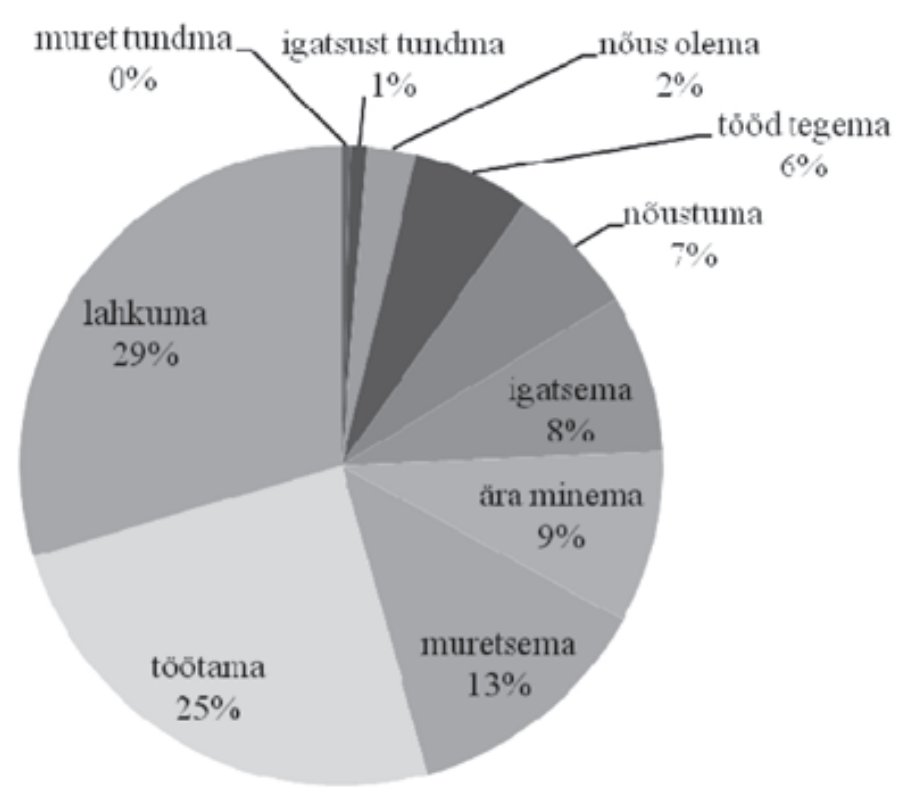

Joonis 1. Alamvalimite osakaal üldvalimis

(vt joonis 2, tabel 2). Peatüki teises osas vaatleme samatähenduslike sünteetiliste ja analüütiliste verbide tekstikasutuse olulisemaid morfoloogilisi klastreid, mille võrdlemine näitab, kui sarnane või erinev on klastrite valik, kui avar või kitsas on nende morfoloogiline varieerumine, milliseid mustreid üldse esineb. Peatüki kolmandas osas kirjeldame iga verbi invariantse klastri sagedamat trigrammi, analüüsime selle leksikaalsemantilise ja morfosüntaktilise varieerumise piire, toome esile tekstikasutuses oluliste trigrammide sarnasuse ja erijooned.

\subsection{Klassid ja alamklassid}

Samatähenduslike sünteetiliste ja analüütiliste verbide kasutusnäidete hulk varieerub pooleteisest tuhandest kahekümne viieni: igatsema (417 näidet), igatsust tundma (43), lahkuma (1543), ära minema (452), töötama (1291), tööd tegema (310), muretsema (663), muret tundma (25), nõustuma (345), nõus olema (128). Samuti erineb nende verbide osakaal üldvalimis. Joonis 1 näitab, et tekstikasutuses on olulisemad sünteetilised verbid lahkuma, töötama, muretsema, igatsema ja nõustuma, mis on loogiline, arvestades nende semantilist hajusust. Tähenduselt 
konkreetsemate analüütiliste verbide esinemus on märgatavalt kitsam, olulisemad on ära minema ja tööd tegema. Verbide nõus olema ja igatsust tundma esinemus jääb marginaalseks. muret tundma kasutus on kaduvväike, mistõttu jääb verbipaar muretsema - muret tundma klasside ja alamklasside kirjeldusest välja, olgugi et muretsema osakaal tekstikasutuses on $13 \%$.

Ülevaade kaheksa verbi (lahkuma, töötama, ära minema, tööd tegema, igatsema, nõustuma, nõus olema, igatsust tundma) trigrammide esinemusest igas alamvalimis on ära toodud tabelis 1 , kus on trigrammide üldarvuga kõrvuti ainukordsete ning kaks ja enam korda esinenud trigrammide arvandmed.

TABEL 1. Trigrammide hulk alamvalimites

\begin{tabular}{|l|c|c|c|}
\hline Verbid & $\begin{array}{c}\text { Trigrammide } \\
\text { hulk }\end{array}$ & $\begin{array}{c}\text { Ainukordsed } \\
\text { trigrammid }\end{array}$ & $\begin{array}{c}\text { Kaks ja enam korda } \\
\text { esinenud trigrammid }\end{array}$ \\
\hline lahkuma & 1543 & 1185 & 358 \\
\hline töötama & 1291 & 1041 & 250 \\
\hline ära minema & 452 & 234 & 218 \\
\hline tööd tegema & 310 & 200 & 110 \\
\hline igatsema & 417 & 334 & 83 \\
\hline nõustuma & 345 & 264 & 33 \\
\hline nõus olema & 128 & 95 & 5 \\
\hline igatsust tundma & 43 & 38 & 1138 \\
\hline Kokku & 4529 & 3391 & \\
\hline
\end{tabular}

Ainukordsete trigrammide suhe kaks ja enam korda kasutatud trigrammidesse on $75 \%$ vs. $25 \% .{ }^{6}$ Analüüsiks sobiv optimaalne trigrammide hulk on arvutatud valemi $\mathrm{k} \approx \sqrt{\mathrm{n}}: 2$ alusel, kus $k$ tähistab optimaalsuskoefitsienti

$6 \quad$ Protsendi arvutamisel on aluseks trigrammide maht: ainukordsetel 10173 sõnet (3391 trigrammi x 3 sõnet); kaks ja enam korda esinenud trigrammidel 3414 sõnet (1138 trigrammi x 3 sõnet), valimi üldmaht on 13587 sõnet. Nende andmete põhjal moodustavad ainukordsed $74,8730 . . \approx 75 \%$ ja kaks ning enam korda esinenud $25,1269 . . \approx 25 \%$ üldvalimi mahust. 
ja $n$ kaks ning enam korda esinenud trigrammide mahtu (3414 sõnet): $\mathrm{k}$ $=29,2147 . . \approx 29$. Optimaalsuskoefitsiendi järgi on kolme verbipaari (lahkuma - ära minema, töötama - tööd tegema, nõustuma - nõus olema) ja igatsema-verbi kasutuse analüüsiks materjali piisavalt. Erandiks on analüütiline verb igatsust tundma, mille kasutamise kohta ei saa viie näite põhjal midagi järeldada (vt tabel 1). Kuna igatsust tundma sisaldavate trigrammide esinemus on ülejäänud verbidega võrreldes marginaalne (1\%), siis jääb ka verbipaar igatsema - igatsust tundma edasisest analüüsist välja (vt joonis 2). Niisiis kirjeldame morfoloogiliste klasside ja alamklasside üldisi kasutustendentse kolme verbipaari põhjal: lahkuma - ära minema, töötama - tööd tegema ja nõustuma - nõus olema. Kõrvale jäetud kahe verbipaari (muretsema - muret tundma ja igatsema - igatsust tundma) andmeid kasutame vastavalt vajadusele võrdlusmaterjalina.

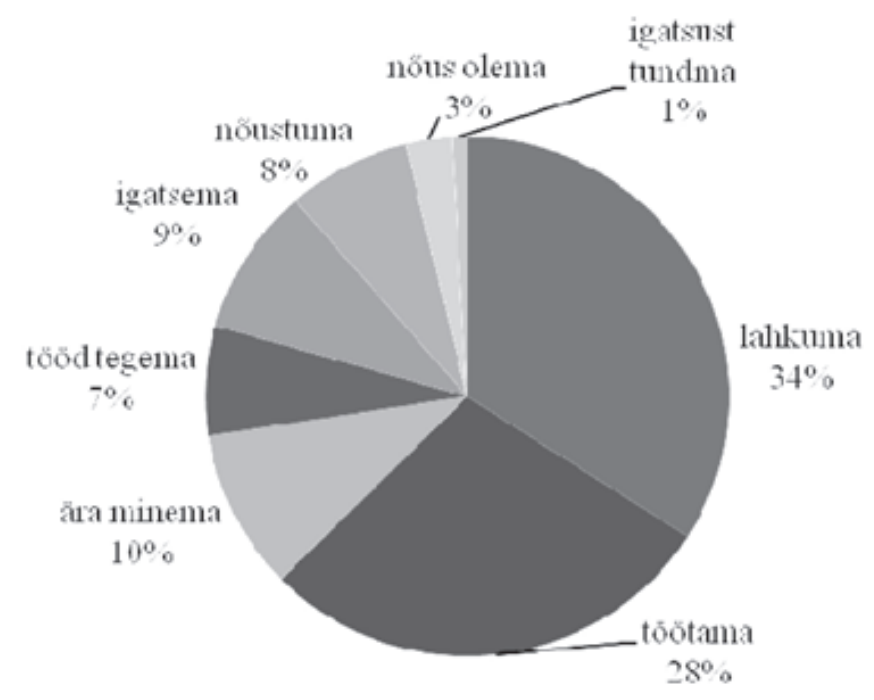

Joonis 2. Verbide osakaal valimis, arvutatuna trigrammide alusel

Iga verbi kaks ja enam korda kasutatud trigrammid jagunevad kahte morfoloogilisse klassi: verbialgulised (325) ja verbilõpulised trigrammid (722), vt tabel 2. Tavalisemad on verbilõpulised trigrammid (paiknevad verbist vasakul), mida esineb ligi kaks korda sagedamini.

Kummagi morfoloogilise klassi sees eristuvad trigrammi keskmise komponendi järgi alamklassid, mis on tabelis 2 reastatud esinemissageduse ja osakaalu alusel. 
TABEL 2. Verbialgulised ja verbilõpulised alamklassid

\begin{tabular}{|c|c|c|c|c|c|c|}
\hline \multirow[b]{2}{*}{ Verbid } & \multicolumn{2}{|c|}{ Verbialguline klass } & \multirow{2}{*}{$\begin{array}{l}\text { Osa- } \\
\text { kaal }\end{array}$} & \multicolumn{2}{|c|}{ Verbilõpuline klass } & \multirow{2}{*}{$\begin{array}{l}\text { Osa- } \\
\text { kaal }\end{array}$} \\
\hline & $\begin{array}{l}\text { Alam- } \\
\text { klassid }\end{array}$ & Sagedus & & $\begin{array}{l}\text { Alam- } \\
\text { klassid }\end{array}$ & Sagedus & \\
\hline lahkuma & $\begin{array}{l}\text { VD- } \\
\text { VV- } \\
\text { VJ- } \\
\text { VS- } \\
\text { VP- }\end{array}$ & $\begin{array}{r}49 \\
24 \\
23 \\
21 \\
8\end{array}$ & $\begin{array}{r}39 \% \\
19 \% \\
18 \% \\
17 \% \\
7 \%\end{array}$ & $\begin{array}{l}-S V \\
-D \\
-V V\end{array}$ & $\begin{array}{l}92 \\
76 \\
62\end{array}$ & $\begin{array}{l}40 \% \\
33 \% \\
27 \%\end{array}$ \\
\hline ära minema & $\begin{array}{l}\text { VD- } \\
\text { VV- }\end{array}$ & $\begin{array}{l}29 \\
10\end{array}$ & $\begin{array}{l}74 \% \\
26 \%\end{array}$ & $-\mathrm{DV}$ & 179 & $100 \%$ \\
\hline töötama & $\begin{array}{l}\text { VD- } \\
\text { VS- }\end{array}$ & $\begin{array}{l}63 \\
26\end{array}$ & $\begin{array}{l}71 \% \\
29 \%\end{array}$ & $\begin{array}{l}-\mathrm{VV} \\
-\mathrm{SV} \\
-\mathrm{DV}\end{array}$ & $\begin{array}{l}63 \\
55 \\
43\end{array}$ & $\begin{array}{l}39 \% \\
34 \% \\
27 \%\end{array}$ \\
\hline tööd tegema & $\begin{array}{l}\text { VS- } \\
\text { VD- }\end{array}$ & $\begin{array}{l}8 \\
8\end{array}$ & $\begin{array}{l}50 \% \\
50 \%\end{array}$ & -SV & 94 & $100 \%$ \\
\hline nõustuma & $\begin{array}{l}\text { VS- } \\
\text { VV- } \\
\text { VD- } \\
\text { VP- }\end{array}$ & $\begin{array}{r}20 \\
11 \\
6 \\
3 \\
\end{array}$ & $\begin{array}{r}50 \% \\
27 \% \\
15 \% \\
8 \% \\
\end{array}$ & $\begin{array}{l}-\mathrm{VV} \\
-\mathrm{DV} \\
-\mathrm{SV} \\
-\mathrm{PV}\end{array}$ & $\begin{array}{r}18 \\
11 \\
8 \\
4 \\
\end{array}$ & $\begin{array}{l}44 \% \\
27 \% \\
19 \% \\
10 \% \\
\end{array}$ \\
\hline nõus olema & VD- & 16 & $100 \%$ & $-D V$ & 17 & $100 \%$ \\
\hline Kokku & 368 & & & 770 & & \\
\hline
\end{tabular}

Optimaalsuskoefitsiendi $\mathrm{k} \approx 29$ järgi saab tõetruud infot järgmiste alamklasside ja verbide kohta: 1) verbialgulistest vaid alamklassi verb-adverb ehk VD- alusel, milles on kasutatud kahte sünteetilist ja ühte analüütilist verbi: töötama 63, lahkuma 49 ja ära minema 29 trigrammi; 2) olulisi verbilõpulisi alamklasse on kolm: adverb-verb ehk -DV - ära minema 179, lahkuma 76, töötama 43 trigrammi; substantiiv-verb ehk -SV - tööd tegema 94, lahkuma 92, töötama 55 trigrammi ja verb-verb ehk -VV töötama 63, lahkuma 62 trigrammi. Seega on samatähenduslike sünteetiliste ja analüütiliste verbide trigrammide esinemus alamklassides piiratud põhiliselt ühe verbialgulise (VD-) ja kolme verbilõpulise (-DV, -SV ja -VV) alamklassiga. 
Kui võrrelda morfoloogilisi alamklasse, mis analüüsitavate verbide kasutuses esile tulid (siin ja edaspidi vt tabel 2), siis saab kirjeldada verbialguliste ja verbilõpuliste alamklasside esinemust.

Sünteetilisele verbile lahkuma järgneb tavaliselt adverb (verbialguline alamklass VD-), harvem verb (VV-) ja konjunktsioon (VJ-); verbile eelneb tavaliselt substantiiv (verbilõpuline alamklass -SV), harvem adverb (-DV) ja verb (-VV). Seega tulevad erinevates positsioonides esile erinevad morfoloogilised struktuurid, mis viitab üsna avarale sõnaliigilisele varieerumisele. Analüütilise verbi ära minema kasutus on kitsam: olenemata positsioonist seob see verb endaga enamasti adverbi (VD- ja -DV), verbialgulises alamklassis ka verbi (VV-), kuid esinemus on poole väiksem.

töötama-verbi paremas ning vasakus kontekstis kasutatakse tavaliselt adverbi (VD- ja -DV), harvem substantiivi (VS- ja -SV). Verbilópulise klassi sagedam alamklass sisaldab verbi (-VV). Analüütilise verbi tööd tegema põhiline kasutusmuster tuleb esile verbist vasakul koos eelneva substantiiviga (-SV). Selle verbipaari näitel on selgelt näha morfoloogiliste struktuuride piiratus (kaks mustrit), mis analüütilise verbi puhul on veelgi kitsam - see on piiratud nii positsiooni (verbilõpuline alamklass) kui ka sõnaliigiga (substantiiv).

Sünteetilisele verbile nõustuma järgneb enamasti substantiiv (alamklass VS-), harvem verb (alamklass VV-) ning eelneb verb (alamklass -VV), harvem adverb (alamklass -DV). Koos analüütlise verbiga nõus olema on nii verbist paremal kui ka vasakul kasutatud ainult adverbi (VD- ja -DV). Seega on ka siin sünteetilise verbi morfoloogiliste alamklasside sõnaliigiline varieerumine tunduvalt avaram kui samatähenduslikul analüütilisel verbil.

Alamklasside analüüsi tulemused näitavad järgmist.

1) Samatähenduslike sünteetiliste ja analüütiliste verbidega esile tulnud alamklasside morfoloogilise varieerumise avarus/piiratus ning esinemissagedus on pöördvõrdelises seoses: sünteetilistel verbidel avaram varieerumine (kuni viis alamklassi, v.a töötama) ja väiksem sagedus, analüütilistel üks-kaks alamklassi, mille sagedus ületab kõikide sünteetiliste 
verbide alamklasside sageduse vähemalt kaks korda - järelikult on analüütiliste verbide puhul tegu pigem kinnistunud struktuuridega.

2) Samatähenduslike sünteetiliste ja analüütiliste verbide esinemus on piiratud positsiooniliselt: neljast olulisest alamklassist kolm (-DV, -SV ja -VV) esinevad verbist vasakul, üks alamklass verbist paremal (VD-).

3) Sageduse poolest eristuvad alamklasside seas adverbi sisaldavad verbialgulised (VD-) ja -lõpulised alamklassid (-DV), mis on kooskõlas eesti keele tekstikasutuse varasemate uurimistulemustega (nt Trainis \& Allkivi 2014).

4) Samatähenduslike sünteetiliste verbide alamklasse on rohkem, neid kasutatakse sagedamini, v.a töötama; analüütilistel verbidel on üks või kaks alamklassi: ära minema (verbilópuline -DV ja verbialgulised VD-, VV-), töö tegema (verbilõpuline -SV ja verbialgulised VS-, VD-), nõus olema (verbialguline VD- ja verbilõpuline -DV) - nende morfoloogiline varieerumine on piiratud ning suure kasutussageduse tõttu kinnistunud; erandiks on sünteetiline verb töötama, millel on samuti kaks verbialgulist alamklassi (VD- ja VS-) - järelikult on ka töötama-verbi puhul tegu struktuuride kinnistumisega, mille eelduseks võib pidada verbi üldist kõrget kasutussagedust.

\subsection{Morfoloogilised klastrid}

Morfoloogiliste klastrite kirjeldamise aluseks on trigrammide jagunemine verbialgulise ja verbilõpulise morfoloogilise klassi alamklasside vahel (siin ja edaspidi vt tabel 3). Iga klaster moodustub kaks ja enam korda esinenud trigrammide sõnaliigijärjendite alusel. Tuleb silmas pidada, et sõnaliigijärjendid kui morfoloogilised struktuurid ei pruugi kokku langeda sünteetiliste ja analüütiliste verbide eeldatava positsiooniga struktuuris, sest verbe kasutatakse erinevates grammatilistes vormides, millel on erinevad morfosüntaktilised funktsioonid. Oma osa on siin ka predikaadi sõnajärjel, kus mineviku liitajavormi ja liitpredikaadi komponente lahutab tavapäraselt adverb või mõni muu sõnaliik adverbiaali funktsioonis. Mustrina esineb seda enamasti analüütiliste verbidega 
VDV-struktuuri jaatavas ja eitavas kõnes: oli ammu lahkunud - oli lahkunud ammu - ammu oli lahkunud; polnud veel lahkuda <jõudnud> veel polnud lahkuda <jõudnud $>$ - lahkuda polnud veel <jõudnud $>$; olete küll tööd <teinud> - küll olete tööd teinud - küll olete teinud tööd - tööd teinud olete küll jne; on tarvis tööd <teha> - on tarvis teha tööd - tarvis on teha tööd - tööd teha on tarvis jne. Selliseid trigramme on käsitletud nii verbialguliste kui ka -lõpulistena, sest sama lingvistiline nähtus võib tulla mustrina esile mõlemas positsioonis.

TABEL 3. Morfoloogilised klastrid

\begin{tabular}{|c|c|c|c|c|c|c|}
\hline \multirow[t]{2}{*}{ Verbid* } & \multicolumn{2}{|c|}{$\begin{array}{c}\text { Verbialgulised } \\
\text { klastrid }\end{array}$} & \multirow{2}{*}{ Osakaal } & \multicolumn{2}{|c|}{$\begin{array}{l}\text { Verbilõpulised } \\
\text { klastrid }\end{array}$} & \multirow[t]{2}{*}{ Osakaal } \\
\hline & Klaster & Sagedus & & Klaster & Sagedus & \\
\hline \multirow{11}{*}{$\begin{array}{l}\text { lahkuma } \\
124 \text { / } 230\end{array}$} & VDV & 30 & $24 \%$ & SVV & 47 & $20 \%$ \\
\hline & VJV & 23 & $19 \%$ & VDV & 30 & $13 \%$ \\
\hline & VSV & 14 & $11 \%$ & DDV & 30 & $13 \%$ \\
\hline & VVV & 11 & $9 \%$ & JSV & 23 & $10 \%$ \\
\hline & VDS & 10 & $8 \%$ & DSV & 23 & $10 \%$ \\
\hline & VDD & 9 & $7 \%$ & SSV & 16 & $7 \%$ \\
\hline & VSS & 7 & $6 \%$ & SDV & 16 & $7 \%$ \\
\hline & VVP & 7 & $6 \%$ & VVV & 15 & $6 \%$ \\
\hline & VVS & 6 & $5 \%$ & VSV & 13 & $6 \%$ \\
\hline & VPD & 4 & $3 \%$ & PSV & 11 & $5 \%$ \\
\hline & VJS & 3 & $2 \%$ & ASV & 6 & $3 \%$ \\
\hline \multirow{4}{*}{$\begin{array}{l}\text { ära } \\
\text { minema } \\
43 \text { / } 179\end{array}$} & VDV & 29 & $67 \%$ & DDV & 94 & $53 \%$ \\
\hline & VVD & 10 & $23 \%$ & SDV & 52 & $29 \%$ \\
\hline & VPS & 2 & $5 \%$ & VDV & 33 & $18 \%$ \\
\hline & VPV & 2 & $5 \%$ & & & \\
\hline \multirow{9}{*}{$\begin{array}{l}\text { töötama } \\
89 \text { / } 161\end{array}$} & VDD & 32 & $36 \%$ & SVV & 34 & $21 \%$ \\
\hline & VDS & 25 & $28 \%$ & SSV & 28 & $17 \%$ \\
\hline & VSS & 14 & $16 \%$ & PSV & 27 & $17 \%$ \\
\hline & VSD & 12 & $13 \%$ & DVV & 19 & $12 \%$ \\
\hline & VDV & 6 & $7 \%$ & DDV & 17 & $11 \%$ \\
\hline & & & & PDV & 12 & $7 \%$ \\
\hline & & & & PVV & 10 & $6 \%$ \\
\hline & & & & SDV & 8 & $5 \%$ \\
\hline & & & & VDV & 6 & $4 \%$ \\
\hline
\end{tabular}




\begin{tabular}{|l|l|l|r|l|r|r|}
\hline & VDS & 8 & $50 \%$ & DSV & 40 & $43 \%$ \\
töö & VSV & 6 & $37 \%$ & ASV & 20 & $21 \%$ \\
$16 / 94$ & VSS & 2 & $13 \%$ & PSV & 17 & $18 \%$ \\
& & & & SSV & 13 & $14 \%$ \\
& & & & VSV & 4 & $4 \%$ \\
\hline & VSJ & 8 & $20 \%$ & SVV & 6 & $15 \%$ \\
& VSS & 6 & $15 \%$ & VDV & 6 & $15 \%$ \\
& VVS & 6 & $15 \%$ & VVV & 6 & $15 \%$ \\
nõustuma & VDV & 6 & $15 \%$ & DDV & 5 & $12 \%$ \\
$40 / 41$ & VVV & 5 & $12 \%$ & JSV & 5 & $12 \%$ \\
& VSD & 3 & $8 \%$ & DVV & 4 & $10 \%$ \\
& VPD & 3 & $8 \%$ & VSV & 3 & $7 \%$ \\
& VSV & 3 & $7 \%$ & DPV & 2 & $5 \%$ \\
& & & & JPV & 2 & $5 \%$ \\
& & & & PVV & 2 & $4 \%$ \\
\hline nõus olema & VDV & 9 & $56 \%$ & VDV & 9 & $53 \%$ \\
$16 / 17$ & VDP & 7 & $44 \%$ & DDV & 8 & $47 \%$ \\
\hline
\end{tabular}

* Arvandmed näitavad klastrite sagedust verbist paremal ja vasakul, nt lahkuma 124 / 230.

Erinevate verbide klastrikasutuse võrdlus annab konkreetsema ettekujutuse sünteetiliste ja analüütiliste verbide tekstikasutuse invariantsetest morfoloogilistest struktuuridest, nende sõnaliigilise varieerumise piiridest ja võimalike mustrite kujunemisest.

Invariantsed klastrid eristuvad sageduse alusel ja tulevad selgelt välja sünteetiliste verbidega lahkuma ning töötama. nõustuma-verbil leidub kokkulangeva sagedusega klastreid, mistõttu invarianti pole võimalik määrata. Suure hulga lähedase esinemissagedusega klastrite alusel hakkavad kujunema mustrid, milles võib näha ühe komponendi vaba sõnaliigilist varieerumist. Analüütilistel verbidel on piir invariandi ja variantide vahel tunduvalt selgem ja ühesem.

Verbist paremal olevate morfoloogiliste struktuuride seas on sagedam adverbi sisaldav struktuur VDV (lahkuma, ära minema, nõus olema) ja verbist vasakul substantiivi sisaldav SVV (lahkuma, töötama). See on kooskõlas alamklasside esinemusega (vt eespool), kus verbialguliste seas on valdav VD-struktuur (töötama, lahkuma - ära minema) ja verbilõpulistes -DV (lahkuma - ära minema, töötama), järgnevad 
-SV (töötama - tööd tegema, lahkuma) ja -VV (töötama, lahkuma). Verbilõpulise -DV struktuuri põhjal moodustavad mustreid verbipaar lahkuma - ära minema ja sünteetiline verb töötama; verbilópulise -SV struktuuri alusel tuleb esile mustreid verbipaariga töötama - tööd tegema, harvem sünteetilise verbiga lahkuma.

Järgnevalt kirjeldame iga verbi klastrite sõnaliigilise varieerumise alusel moodustuvaid mustreid.

\section{lahkuma}

1) Verbist paremal moodustub viis erinevat mustrit, mille morfoloogiline varieerumine on üsna avar, sagedus aga peaaegu kaks korda väiksem (124 kordust) kui verbist vasakule jäävas kontekstis esile tulnud kolme rikkalikult varieeruva mustri puhul (230 kordust).

2) Sagedam muster verbist paremal on invariantsel klastril (VDV > VDS $>$ VDD), kus viimase komponendina varieeruvad verb, substantiiv ja adverb: VDV oli ammu lahkunud, polnud veel lahkuda <jõudnud >> VDS lahkusime sealt Kassitoomelt, lahkuge kohe saalist, lahkus siis Eia $<$ toast $>$, lahkuma siit ilmast > VDD lahkus ju ometi, lahkuma küll alles, lahkunud nii vaikselt, lahkunud siit juba - kokku 49 korda. Ülejäänud klastrites on kaks korda vähem näiteid, kuid nende alusel moodustub neli mustrit, kus varieerub samuti klastri viimase komponendi sõnaliik: 1) VVV lahkuda ei tahtvat > VVP lahkuda soovin sellest > VVS olime lahkunud volbriööl; 2) VSV lahkuda meeldib Tallinnast > VSS lahkub patsient Bigart; 3) VJV lahkuma ja jätkama > VJS lahkub ja töölised. Kuigi klastri VPD (lahkuda ta siit) osakaal alamvalimis on marginaalne, on see siiski omaette mustrina esile tulnud.

3) Verbist vasakul on vastupidi - invariantse klastri muster SVV kodust jõuab lahkuda, Vellol tuli lahkuda, Eia peab lahkuma, publik oli lahkunud > VVV olin otsustanud lahkuda (kokku 62 näidet) jääb sageduselt alla ülejäänud klastrite alusel moodustunud kahele mustrile: 1) VDV asutab parajasti lahkuma, oli siit lahkunud, tahtis solvunult lahkuda > DDV alles äsja lahkus, siit igaveseks lahkunud > SDV eurooplased sealt lahkusid, Andreas vahepeal lahkub - kokku 
76 korda; 2) DSV <oli> delikaatselt toast lahkunud, <tahab > kiiresti Soomest lahkuda, <on> siit ilmast lahkunud > JSV ja poiss lahkus, kui vennanaine lahkunud <oli>, et pilved lahkuvad > SSV <hakkasid> külalised talust lahkuma, katse elust lahkuda > VSV oli toast lahkunud, soovitab Romanil lahkuda, pidi poisist lahkuma > PSV me kirikust lahkusime, see hing lahkub > ASV väike tüdruk lahkub, õigel ajal lahkuda, õnnetust pesast lahkuda - kokku 92 korda.

\section{ära minema}

1) Verbist paremal tuleb esile kolm mustrit, kaks neist ei varieeru morfoloogiliselt ja kolmas on marginaalne; verbist vasakul on üks morfoloogiliselt varieeruv muster, mille sagedus on verbiga algavatest struktuuridest neli korda suurem (vastavalt 179 ja 43 korda).

2) Verbialguliste struktuuride invariantne klaster VDV moodustab omaette mustri, nt on (oleks) ära läinud. Tegu on enamasti analüütilise verbi mineviku liitaja vormidega. Teine muster VVD moodustub käskiva kõneviisi alusel: ära mine sinna (kuhugi, veel, $k a$ ). Kolmas muster kujuneb samuti käskiva kõneviisi alusel, kuid selle esinemus on marginaalne: VPS $<$ ära $>$ mine tema koju $>$ VPV $<$ ära $>$ mine temaga mängima.

3) Verbilõpuliste klastrite invariantse klastri DDV alusel moodustub üks muster, kus esikomponendina varieeruvad adverb, substantiiv ja verb: DDV kiiremini ära läheksid, <pean > tõesti ära minema, <oli> kuhugi ära läinud > SDV allikalt ära läheks, arust ära läinud > VDV oleks (on) ära läinud, tahtis ära minna, peab ära minema, hakkas ära minema.

\section{töötama}

1) Verbist paremal tuleb esile kaks suhteliselt vähe varieeruvat mustrit ja vasakul kolm üpris rikkalikult varieeruvat mustrit; nende sagedus verbist paremal on ligi kaks korda väiksem (89) kui verbist vasakul (161).

2) Sagedam muster verbist paremal moodustub invariantse klastri VDD alusel, nt töötan siiski veel, töötas hoopis seal, töötab edaspidi välja > 
VDS töötas ju põhikohaga, töötasid otseselt televisioonis > harva VDV $<$ pole > töötada varem saanud, kus struktuuri viimase komponendina varieeruvad adverb, substantiiv ja verb. Teine muster koosneb kahest klastrist: VSS töötas laevadel meelelahutusprogrammides, töötab restoranis abitöölisena, töötas Merle Malvik, töötas Merikese mõte > VSD töötas (töötab) võrk küll, <süda> töötas rinnus nagu.

3) Sagedam muster verbist vasakul moodustub invariantse klastri SVV alusel, nt kell ei tööta, mõtted ei tööta, arvutiga oskad töötada $>$ DVV enam ei tööta, kunagi võiksid töötada > PVV see ei tööta, ma ei tööta, ta on töötanud, ma tahaksin töötada, kus esikomponendina varieeruvad substantiiv, adverb ja pronoomen. Ülejäänud klastrite alusel tuleb esile veel kaks mustrit: 1) SSV Mati Tera töötas, loomaarsti süda töötas > PSV see arvuti töötab, mu mõte töötas ja 2) DDV <kus sa> üldse praegu töötad, hirmsasti üle töötanud, vaja välja töötada > PDV te ju töötasite, meil sisse töötatud > SDV tähelepanuvõime veel töötas, naine kah töötab, asutamisele vastu töötada > VDV peavad hoolsasti töötama, olen siin töötanud.

\section{tööd tegema}

1) Analüütilise verbiga tööd tegema moodustub verbist paremal kaks mustrit - üks neist on morfoloogiliselt mittevarieeruv ja teine vähe varieeruv; verbist vasakul on üks rikkalikult varieeruv muster. Mustrite esinemus verbist paremal on ligi viis korda väiksem (19) kui verbist vasakul (94).

2) Verbist paremal on kaks võrdselt kasutatud mustrit: 1) invariantne klaster VDS, kus analüütilist verbi on kasutatud erinevates mineviku liitaja vormides või liitpredikaadis koos modaal(ad)verbiga, nt olete küll tööd $<$ teinud>, on tarvis tööd <teha>, peab ka tööd <tegema > ja 2) VSV tulin tööd tegema, rabasin tööd teha, pidi tööd tegema > VSS oli suvel tööd $<$ teinud>, oppisin kodutalus tööd <tegema>, oskasin talus tööd <teha>, kus viimase komponendina varieeruvad verb ja substantiiv.

3) Verbist vasakul moodustub üks rikkalikult varieeruv muster, kus esikomponendiks võib olla adverb, adjektiiv, pronoomen, substantiiv ja verb: DSV < peab> ju tööd tegema, kõvasti tööd tegema, siin tööd 
teha $>$ ASV <pean> mõttetut tööd tegema, <on> füüsilist tööd teinud $>$ PSV kes tööd teeb, oma tööd tegema, meie tööd teeme > SSV õpilastega tööd teha, talus tööd teha, <on> põllul tööd teinud, inimestel tööd teha > VSV üritab tööd teha, tahtsin tööd teha, rabasin tööd teha, rühmab tööd teha, samuti oli suvel tööd <teinud>, lase rahval tööd $<$ teha>, peab ka tööd <tegema>.

\section{nõustuma}

1) Verbist paremal on kaks morfoloogiliselt varieeruvat ja kaks mittevarieeruvat ebaolulist mustrit, samas kui vasakul on neli rikkalikult varieeruvat mustrit. Klastrite sagedus mõlemas positsioonis on sisuliselt sama (vastavalt 40 ja 41). Verbialguliste ja -lõpuliste klastritemustrite arv ning morfoloogiline varieerumine on sünkroonne: kaks korda rohkem klastreid (8 ja 10) kui mustreid (4 ja 4). Võrdlemisi suure arvu klastrite madal sagedus (alla optimaalsuskoefitsiendi $\mathrm{k} \approx 29$ ), suhteliselt suur mustrite hulk nii verbist vasakul kui ka paremal ja avar morfoloogiline varieerumine näitavad, et sünteetilise verbi nõustuma kasutuses pole kindlalt väljakujunenud mustreid pigem on tegu nelja erineva morfoloogiliselt varieeruva variandiga.

2) Verbialgulise invariantse klastri VSJ alusel moodustub muster, kus viimase komponendina varieeruvad konjunktsioon, substantiiv, adverb ja verb: VSJ nõustuvad naised ning > VSS nõustus vend Andreas, nõustus Olavi ettepanekuga > VSD nõustus Meeri jalamaid, nõustusid mungad üksmeelselt > VSV nõustus Horn kiirustades, nõustuks katusele ronima. Teine muster on VVS ei nõustunud tüdruk, nõustus minema riskil > VVV ei nõustunud tegema, nõustuda ei saa. Ülejäänud kaks klastrit VDV (nõustus vist olema) ja VPD (nõustusin ma kohe) ei moodusta morfoloogiliselt varieeruvaid mustreid.

3) Verbilõpuliste klastrite seas pole selget invarianti, sest sama osakaaluga tuleb esile kolm morfoloogiliselt erinevat klastrit SVV, VDV ja VVV. Mustreid on kokku neli: 1) sagedam muster kujuneb klastri SVV esikomponendi varieerumise alusel: SVV Luik poleks nõustunud, hing ei nõustunud > VVV ei tahtnud nõustuda, olid sunnitud nõustuma > DVV kindlasti ei nõustunud, ju otsustasin nõustuda > 
PVV ta ei nõustunud, ma jõuan nõustuda; 2) VDV oleksin ilmselt nõustunud, jääb vaid nõustuda, pidi juba nõustuma > DDV siis äkitselt nõustusin; 3) JSV et Helve nõustub, kui tehinguga nõustub > VSV nõustus Horn kiirustades; 4) DPV eks ma nõustusin, miks sa nõustusid, nü̈̈d ta nõustus > JPV kui ta nõustub.

\section{nõus olema}

1) Analüütilise verbi tekstikasutus on selgelt piiratud - nii verbist paremal kui ka vasakul tuleb sama sagedusega (16 ja 17) esile üks morfoloogiliselt vähe varieeruv muster. Tegu on kinnistunud struktuuridega, mille aluseks kindlad lingvistilised kooslused: verbist paremal - kes oli (on) nõus mida tegema ja kes oli (on) nõus kellega; verbist vasakul - modaalne liitpredikaat, nagu tuleb nõus olla, ei tohtinud nõus olla.

2) Verbialguliste struktuuride invariantse klastri VDV viimase komponendi sõnaliigi varieerumise alusel moodustub üks muster: VDV oli nõus maksma > VDP oli nõus minuga, pole nõus oma <vennaga $>$.

3) Verbilõpuliste struktuuride invariandi VDV alusel moodustub samuti üks muster: VDV <ei> pruukinud nõus olla, tuleb nõus olla > DDV ülepea nõus olen, <tuleb> muidugi nõus olla.

Niisiis näitavad samatähenduslike sünteetiliste ja analüütiliste verbide morfoloogiliste struktuuride hulk, sagedus ja mustrite varieerumine, kuivorrd tihedalt need nähtused on seotud mustrite paiknemisega verbist paremal või vasakul. Järelikult on mustri kujunemisel positsioon üks formaalsetest tunnustest, mis eristab sünteetilise ja analüütilise verbi kasutust. Analüüsi tulemused näitavad järgmist.

1) lahkuma - ära minema. Sünteetilisest verbist vasakul tuleb esile vähem mustreid (kokku kolm), kuid nende esinemissagedus on poole suurem, nagu ka morfoloogiline varieerumine, samas kui verbist paremal on rohkem mustreid (kokku viis) ja nende varieerumine väiksem. Seega kinnistuvad sünteetilise verbi kasutusmustrid eelistatult verbist vasakul. Sama tendents on veel paremini nähtav analüütilise verbiga, millest vasakul on vaid üks väga sageli esinev ja 
morfoloogiliselt vähe varieeruv muster, paremal aga kolm harva esinevat mittevarieeruvat mustrit. Niisiis on analüütilise verbi mustrid morfoloogiliselt ja esinemuse poolest selgemalt piiratud ja rohkem kinnistunud kui sünteetilisel verbil.

2) töötama - tööd tegema. Sünteetilise, eriti aga analüüilise verbi puhul eelistatakse verbist vasakul paiknevaid mustreid. Analüütilisel verbil on selles positsioonis neli korda ja sünteetilisel poole suurem esinemus kui verbist paremal. Mõlema verbi kasutuses ilmnenud mustrite hulk on väike (sünteetilisest verbist paremal kaks ja vasakul kolm, analüütilisel vastavalt kaks ja üks), kuid morfoloogiline varieerumine seevastu avar (analüütilisel verbil peamiselt verbist vasakul). Niisiis on paaril töötama - tööd tegema vähe mustreid, kuid rikkalik morfoloogiline varieerumine. Ilmselt mängib selles oma osa töötama-lekseemi üldine suur kasutussagedus, mida ei saa öelda lahkuma ja nõustuma kohta. Seega on olemas soodumus teatud morfoloogiliste mustrite kinnistumiseks verbi ees või järel. Siit tuleneb sünteetilise ja analüütilise verbi mustrite kvantitatiivne samalaadsus, erinevused puudutavad morfoloogilist varieerumist.

3) nõustuma - nõus olema. Kuna mõlema verbi klastrisagedus jääb alla optimaalsuskoefitsiendi, siis ei saa kindlalt väita, et verbist paremal ja vasakul leitud mustrid on välja kujunenud. Kõik esile tulnud sama väikese sagedusega klastrid kandideerivad invariandi staatusele. Suhteliselt suur hulk morfoloogiliselt avara varieerumisega mustreid annab sünteetilise verbi puhul märku pigem verbi avatusest erinevatele kontekstidele. Seevastu analüütilisest verbist paremal ja vasakul on üks kinnistunud muster, mille aluseks on kindlad lingvistilised struktuurid.

\subsection{Invariantsed trigrammid}

Kirjeldus tugineb invariantsete klastrite kõige sagedamale trigrammile ja annab seetõttu ülevaate morfosüntaktilise varieerumise tekstikasutuse tendentsidest. Nende trigrammide võrdlemine võimaldab 
samatähenduslike sünteetiliste ja analüütiliste verbide kasutuses esile tuua nii lingvistilist sarnasust kui ka erinevusi, millest saab teavet verbide funktsionaalse potentsiaali kohta. Keskne küsimus on, kas leidub mingeid märke sellest, et samatähenduslikke sünteetilisi ja analüütilisi verbe võiks kirjeldada sõnastikus ühe verbi sünteetilise ja analüütilise vormina või on tegu semantiliselt lähedaste, kuid iseseisvate leksikaalsete üksustega.

\section{lahkuma - ära minema}

Nii sünteetilist kui ka analüütilist verbi kasutatakse valdavalt otsetähenduses: vastavalt 'kuskilt, mingist keskkonnast ära minema' ja 'lahkuma' Need semantilised määrangud moodustavad tautoloogilise ringi ('kuskilt ära minema' $\leftrightarrow$ 'kuskilt lahkuma'), mis tõendab verbide tihedat semantilist seost. Mõlemat verbi kasutatakse VDV-struktuuris, milles tuleb esile kaks kinnistunud morfosüntaktilist mustrit: ühelt poolt mineviku liitaja vormid ja teisalt modaalsed liitpredikaadid. Kirjeldatud piirangud on sünteetilisel ja analüütilisel verbil ühised, mis võimaldab neid käsitleda ühe verbina. Tegu on samatähendusliku sünteetilise ja analüütilise verbi semantilise, morfosüntaktilise ning struktuurse tõmbumisega (sama tähendus ja kasutusmuster). Mõningast lingvistilist varieerumist ja kitsendusi toob sisse adverbiaalne komponent. Nii on sünteetilise verbi puhul eelistatud rõhuadverbe juba ja ka (olin juba lahkunud, võinud ka lahkuda) ning viisiadverbe (oli viisakalt lahkunud, saama väärikalt lah$k u d a)$, mis paiknevad mineviku liitajavormide ja modaalse liitpredikaadi abiverbi finiitvormi järel, samas kui proadverbi siit kasutatakse vaid modaalses liitpredikaadis abiverbide võima ja pidama (harva soovima) finiitvormi järel (võib siit lahkuda, pidin üksi lahkuma, soovima siit lah$k u d a)$. Analüütilise verbi puhul on adverbiaalseks komponendiks alati tegevuse piiritletust markeeriv partikkel ära, mida kasutatakse kas mineviku liitajavormides abiverbi finiitvormi järel $(<t a>$ oli ära läinud, on ära läinud, ongi ära läinud) või modaalses liitpredikaadis abiverbide tahtma, võima ja pidama finiitvormi järel (tahan ära minna, tahaks ära minna, võid ära minna, peame ära minema). Harvem on abiverbi funktsioonis kasutatud faasiverbi (hakkavad ära minema). 
Vaatamata sellele, et verbide lahkuma ja ära minema kasutuses on näha tõmbumist semantika, morfosüntaksi ja struktuuri alusel, tuleb seda juhtumit käsitleda siiski pigem erandi, kui reeglina, sest verbist vasakul paiknevad mustrid on sünteetilisel ja analüütilisel verbil erinevad - vastavalt SVV ja DDV. Kuigi verbide lahkuma ja ära minema sünonüümne varieerumine sõnajärge ning lausestust muutmata on põhimõtteliselt võimalik ja täiesti loomulik (publik oli lahkunud publik oli ära läinud; turvakodust lahkuma peab turvakodust ära minema peab; <peab> ikkagi ära minema <peab> ikkagi lahkuma), ei leia see tegelikult kasutust.

Sünteetilisele verbile omases SVV-struktuuris on tavaline sõnajärg subjekt + predikaat, kus mineviku liitaja vormiks enamasti pluskvamperfekt (mammi oli lahkunud). Harvem esineb inversiivse sõnajärjega liitpredikaat, kus substantiiv elatiivis on käändelise määruse funktsioonis, järgneb lahkuma-verb infinitiivis ja abiverbi finiitvorm (faasi- või modaalverb), nt ärklitoast lahkuma hakkas, turvakodust lahkuma peab. Lisaks otsetähendusele 'kuskilt, mingist keskkonnast ära minema' on lahkuma-verbi kasutatud ka ülekantud tähenduses 'üksteisest v kellestki lahku minema; kedagi maha jätma’ (Maritist lahkuda on) ja piltlikult tähenduses 'surema' (elust otsustas lahkuda).

Analüütilise verbi kasutusele omane DDV-struktuur koosneb kahest adverbist (üks neist verbipartikkel ära) ja $m a$-infinitiivist, nt tõesti (ikkagi, kuhugi, siit) ära minema. Mineviku liitaja vormiks on enamasti pluskvamperfekt (<oli> päriselt ära läinud). DDV-struktuur on morfosüntaktiliselt lihtne ning seetõttu avatud nii morfosüntaktilisele varieerumisele kui ka kinnistumisele. Trigrammi esimese komponendi määruslik põhifunktsioon taandub, esile kerkivad erinevad tekstilised funktsioonid (subjektiivmodaalne hinnang, rõhutamine), mis on adverbilistele struktuuridele verbist vasakul üldiselt omane ja seletatav kui analoogiapõhine ühtlustumine järgneva grammatiseerunud komponendi mõjul (ontoloogiline protsess). Lisaks otsetähendusele 'lahkuma' leidub piltlikke väljendeid nagu <juuksed olid > peast ära minemas ('kiilanema'), millel on spetsiifiline tähendus. 
Sünteetilise ja analüütilise verbi kasutuses kinnistunud mustrid näitavad, et tegu on siiski iseseisvate verbidega. Tõmbumine on vaid semantiline, sellega ei kaasne struktuurset ning morfosüntaktilist tõmbumist, nagu eespool kirjeldatud VDV-struktuuri puhul. See on näide vaba varieerumise ja kinnistunud struktuuride dialektikast, mis toimib keele leksikaalgrammatilises perifeerias.

\section{töötama - tööd tegema}

Seda verbipaari kasutatakse peamiselt otsetähenduses 'töötama, tööga hõivatud olema'. Olenevalt mustri paiknemisest verbist vasakul või paremal erinevad nii verbide tähendused kui ka trigrammi struktuur ja morfosüntaks.

Sünteetilise verbi sagedam muster verbist vasakul on SVV-struktuur eitavas kõnes, mille abil väljendatakse elusa või elutu subjekti võimetust oma funktsiooni täita (kell ei tööta, ka ülekantult - mõtted ei tööta). Substantiiv on tavaliselt ainsuse nominatiivis subjektina, verb töötama eitava kõne preesensis (purskkaev ei tööta, kell ei tööta), harvem minevikus (isa ei töötanud, jaam ei töötanud). Kuna semantiline tunnus 'võimetus oma funktsiooni täita' iseloomustab vaid sünteetilist verbi, siis pole sünonüümsed asendused analüütilise verbiga loomulikud ( ${ }^{*}$ purskkaev ei tee tööd, ${ }^{\star} k e l l$ ei tee tööd).

Analüütilise verbi kasutuses on kinnistunud modaalne DSV-struktuur, milles väljendverbi tööd tegema kasutatakse otsetähenduses 'töötama, tööga hõivatud olema' (vaja tööd teha). Selle struktuuri alusel saab analüütilist verbi asendada sünteetilisega $(<0$ on > vaja tööd teha $\sim$ on vaja töötada). Predikaadi koosseisu kuulub tavaliselt modaaladverb (enamasti vaja) või adverbid, millel erinevad määruslikud (kõvasti, suvel, siis) ja rõhutamise (ometi, $k a$ ) funktsioonid.

Verbist paremal eelistatakse sünteetilist verbi VDD-struktuuris, kus töötama-verbi kasutatakse finiitvormis (tavaliselt imperfekti ainsuse 3. pööre), järgnevad adverbilist päritolu rõhusõna ja ajatähenduslik adverb (töötati isegi öösel) või proadverb kohamääruse funktsioonis (töötas hoopis seal). Tavaliselt on sünteetilist verbi kasutatud otsetähenduses 
'töötama, tööga hõivatud olema'. VDD-struktuur on aluseks ka võrdlustele (nt töötas nagu õlitatult), kus töötama-verbil on sama tähendus, mis verbist vasakul SVV-struktuuris: 'talitlema, funktsiooni või ülesannet täitma'. Samuti on VDD-struktuuril valmidus genereerida sünteetilisest verbist tähenduselt erinevaid uusi analüütilisi verbe (nt välja (sisse, üle) töötama). Selles ilmneb sünteetilise verbi avar potentsiaal keeleliste väljendusvahendite mitmekesistamisel. ${ }^{7}$ Järelikult on keele leksikaalgrammatilises perifeerias varjatult olemas nii keele uuenemise kui ka struktuurse, leksikaalsemantilise ja morfosüntaktilise kinnistumise võimalused. Nende kahe poole dialektika ilmneb läbi tekstikasutuse.

Analüütilisest verbist paremal paiknevatest mustritest on sagedam VDS-struktuur, kus verbi tööd tegema on kasutatud otsetähenduses 'töötama, tööga hõivatud olema'. See struktuur on aluseks modaalsele liitpredikaadile, milles adverb paikneb modaalverbi finiitvormi või modaaladverbi ja analüütilise verbi infiniitvormi vahel (pidin ka tööd tegema, pidin kõvasti tööd tegema; oli vaja (tarvis) tööd teha). Tegu on lingvistilise üksusega, mille kasutuse teeb keeleõppija jaoks raskeks keerukas sõnajärg ja morfosüntaks, nagu ka eespool kirjeldatud verbist vasakul paiknevas DSV-struktuuris.

Niisiis saab töötama ja tööd tegema tähendusühtsusest rääkida vaid otsetähenduses, milles need verbid võivad olla osaliselt sünonüümsed. Verbist vasakul ja paremal paiknevas kontekstis on mõlema verbi tekstikasutus semantiliselt, struktuurselt ning morfosüntaktiliselt diferentseeritud. Verbist vasakul on sünteetilisel ja analüütilisel verbil erinevad tähendused (vastavalt 'võimetus oma funktsiooni täita' ja 'töötama, tööga hõivatud olema'), kasutusmustrid (vastavalt SVV eitavas kõnes ja DSV) ja morfosüntaks. Sünteetiline verb on analüütilisest semantiliselt avaram. Analoogsed piirangud tulevad esile ka verbist paremal: verbide tekstikasutus erineb semantiliselt (vastavalt 'talitlema, funktsiooni või ülesannet täitma' ja 'töötama, tööga hõivatud olema'), struktuurselt

\footnotetext{
$7 \quad$ Varasem uurimus on näidanud, et uusi ühendverbe genereeritakse reeglipäraselt verbist vasakul ja väljendverbe paremal; vastupidine protsess pole küll tüüpiline, kuid täiesti võimalik (vt Eslon 2014a: 28-30).
} 
(vastavalt VDD ja VDS), morfosüntaktiliselt (vastavalt verbi finiitvorm ja modaalne liitpredikaat) ning funktsionaalselt (sünteetilise verbi kasutusega VDD-struktuuris võib kaasneda ja kinnistuda uute keeleüksuste genereerimine (võrdlused, ühendverbid), seevastu analüütilise verbi kasutuses on kinnistunud modaalne liitpredikaat). Nende kahe tendentsi dialektika - funktsionaalne ja semantiline avatus ning funktsioonide kinnistumine - näitab, et töötama ja tööd tegema on kaks erinevat verbi.

\section{nõustuma - nõus olema}

Sünteetilisel ja analüütilisel verbil on ühine otsetähendus 'soostuma', kusjuures soostumist mõistetakse ühelt poolt nõusse jäämise ja teisalt nõus olemisena. Tegu on vaatepunktide erinemisega, mille alusel sünteetiline verb võib tähistada nii piiritlemata (hing ei nõustunud), piiritletud (nõustus Potapov ning) kui ka potentsiaalselt piiritletud tegevust (Enel nõustus magama), analüütiline verb aga seisundit (oli nõus helistama) ja modaalset hinnangut (tuleb nõus olla, ei pruukinud nõus olla). Need semantilised ja leksikaalgrammatilised iseärasused hakkavad määrama sünteetilise ja analüütilise verbi kasutust: nõustuma puhul pole näha selgeid lingvistilisi mustreid, milles üheselt oleksid väljendunud nõusse jäämise erinevad aspektuaalsed tähendused; analüütilise verbi nõus olema tähendus on kitsam ning seotud seisundite ja modaalsete hinnangute väljendamisega.

Verbist vasakul tuleb esile sünteetilise verbi semantilise hägususe ja morfoloogiliste struktuuride avara varieerumise vastavus, mistõttu invariantset trigrammi on raske määrata. Avaralt varieeruv muster moodustub SVV-struktuuri alusel: 1) substantiivile ainsuse nominatiivis subjekti funktsioonis järgneb liitpredikaat (Lamont nõustus minema); 2) substantiiv võib olla käändelise määruse funktsioonis - sel juhul on tegu inversiivse sõnajärjega (jamas osalema nõustusin); 3) pronoomenile ja/või substantiivile nominatiivse subjekti funktsioonis järgneb jaatava või eitava kõne mineviku liitaja vorm (hing ei nõustunud, <ta> ei nõustu$n u d)$; 4) adverbi kasutatakse mineviku liitajavormi või liitpredikaadi ees (kindlasti ei nõustunud, ju otsustasin nõustuda); 5) modaalverb esineb 
koos ma- või da-infinitiiviga jaatavas ja eitavas kõnes (olid sunnitud nõustuma, ei tahtnud nõustuda). Verbi nõustuma on kasutatud enamasti otsetähenduses 'soostuma, nõusse hakkama, nõusse jääma', harva piltlikult väljendites, nagu hing ei nõustunud.

Verbist paremal paiknevas kontekstis eristub invariantne trigramm, milles nõustuma-verb on imperfekti ainsuse 3. pöördes, järgnevad substantiiv ainsuse nominatiivis subjektina ja rinnastavad sidesõnad ja või ning, nt nõustus Aidann ja, nõustus Potapov ning, nõustus Olli ja. Sünteetilist verbi on selles VSJ-struktuuris kasutatud otsetähenduses 'soostuma, nõusse hakkama, nõusse jääma’.

Analüütilist verbi nõus olema on nii verbist vasakul kui ka paremal kasutatud kinnistunud sõnajärjega struktuuris DVD, nt oli nõus helistama, <ei> pruukinud nõus olla, tuleb nõus olla.

Eespool kirjeldatud positsiooniliste, struktuursete ja morfosüntaktiliste piirangute puhul saab otsetähenduses asendada sünteetilist verbi analüütilisega ja vastupidi, mis viitab nende sünonüümsusele: Enel nõustus magama Enel oli nõus magama; <ta $>$ ei nõustunud $\sim<t a>$ ei olnud nõus; kindlasti ei nõustunud kindlasti ei olnud nõus; ei tahtnud nõustuda ei tahtnud nõus olla; nõustus Aidann ja oli Aidann nõus ja; oli nõus helistama $\sim$ nõustus helistama; tuleb nõus olla $\sim$ tuleb nõustuda. Järelikult pole lingvistilise eksperimendi tingimustes kognitiivsete vaatepunktide erinemine nõusse jäämise ja nõus olemise vahel oluline, kuid see muutub oluliseks tekstikasutuses, kui on vaja markeerida tegevuse kulgemist seisundile lähenemise või seisundis olemisena. See on kujukas näide erinevate lingvistiliste ja struktuursete tegurite põimumisest kognitiivsemantiliste, pragmaatiliste ja aspektuaalsete tähenduste väljendamisel tekstis, eriti keeltes, kus puudub grammatiline aspektikategooria. Samuti pole sünteetilisel verbil nõustuma välja kujunenud kindlaid kasutusmustreid ega juurdunud struktuure, samas kui analüütilist verbi nõus olema kasutatakse ühes kinnistunud modaalstruktuuris. Kokkuvõttes on tegu kahe erineva verbiga, mille tekstikasutuses ilmneb vaba varieerumise ja kinnistunud struktuuride dialektika, mis toimib keele leksikaalgrammatilises perifeerias. 


\section{Järeldused}

Käesoleva uurimuse põhieesmärk oli leida vastuseid küsimusele, kas samatähenduslikud sünteetilised ja analüütilised verbid tõmbuvad semantiliselt ja morfosüntaktiliselt, moodustades ühe verbi kaks vormi, või on tegu erinevate verbidega. Selleks võrdlesime nende tähendust ja tekstikasutuse mustreid morfoloogiliste klasside, alamklasside, klastrite ja morfosüntaktiliste trigrammide alusel.

Eeldasime, et semantiliselt lähedased sünteetilised ja analüütilised verbid moodustavad paare tegevuse abstraktsuse/konkreetsuse põhjal, viidates samas selle tunnuse neutraliseerumisele tekstikasutuses. Sünteetiliste ja analüütiliste verbide sünonüümne asendamine näitab, et olenevalt verbi tähendusest ja trigrammi struktuurist saab analüütilist verbi sünteetilisega asendada, kuid vastupidine asendus on võimalik vaid tähenduste kokkulangemisel, st üldtähenduses (nt töötama - tööd tegema), kui sõnajärg ja lausestus ei muutu. Klasteranalüüsi tulemused toovad selgelt esile, et sünteetiliste verbidega on rohkesti erinevaid mustreid, kuid nende esinemissagedus jääb märkimisväärselt (üle kahe korra) alla analüütiliste verbide vähestele mustritele. Selles mõttes on sünteetilised verbid tõepoolest semantiliselt avaramad (abstraktsemad) kui analüütilised, mis võimaldab neid kasutada erinevates kontekstides ja funktsioonides (erandiks töötama-verb, mis kuulub eesti keele sagedamate sõnade hulka, mille tekstikasutusmustrid enamasti välja kujunenud ning VDD-struktuur verbist paremal genereerib võrdlusi ja uusi ühendverbe). Analüütiliste verbide kasutus on sünteetilistest tunduvalt piiratum. Enamasti on tegu juurdunud struktuuridega, milles verbi semantika ja funktsioonid kitsenenud.

Need kaks tendentsi - avardumine ja kinnistumine - ei ole analüüsitud verbipaarides väljendunud ühtlaselt. Näiteks verbidel nõustuma ja nõus olema on üldse raske näha väljakujunenud mustreid. Esile tulevad erinevad struktuurid, mille alusel hakkavad ilmselt kujunema kasutuspiirangud, mis diferentseerivad sünteetilise ja analüütilise verbi valikut. Verbide semantiline hajusus, struktuuride paljusus ja morfosüntaktiline 
varieerumine, uute tekstiliste funktsioonide ilmnemine - kõik see võib pikemas perspektiivis olla aluseks uutele keelelistele arengutele ja muutustele, mida hetkel raske ennustada. Ei ole selge, kas funktsioonide avardumine-kinnistumine võib viia sünteetiliste ja analüütiliste verbide kasutuses kvalitatiivsete niheteni, sh sünteetilise ja analüütilise verbi tõmbumiseni verbipaariks. Ilmselt ei anna hetkel paremat tulemust ka lingvistiline eksperiment teoreetiliselt võimalike sünteetiliste ja analüütiliste verbide kandidaatpaaridega, sest artikli teise autori varasem uurimus vene-eesti verbi-noomeniühendite tõlkesõnastikust leitud kahekümne verbipaari tähendus- ning rektsioonierinevustest on näidanud, et väiksemgi nihe sünteetilise või analüütilise verbi tähenduses tingib muutusi rektsioonistruktuuris ning see välistab paari tekkimise (vt Paeoja 2012). Objektiivsema aluse kandidaatpaaride leidmiseks saaks siis, kui mõõta sünteetilise ja analüütilise verbi semantilise tõmbumise tugevust otsetähenduses. Selle põhjal saame arvnäitaja sünteetilise ja analüütilise verbi semantilise läheduse kohta, kuid see ei anna veel vastust küsimusele, kas tõmbumine on semantiline, kas sellega kaasneb ka struktuurne ja morfosüntaktiline tõmbumine või on tegu keele leksikaalgrammatilises perifeerias kulgeva avarama protsessiga. Neid seoseid pole lihtne üheselt kindlaks teha, sest protsessid leksikaalgrammatilises perifeerias kulgevad sõltumatult, et pakkuda erinevaid võimalusi väljendusvahendite uuendamiseks ja loominguliseks kasutamiseks. Pealegi ei pruugi niisugused protsessid konkreetsete muutusteni üldse viia, sest toimib tasakaal vaba varieerumise ja kinnistumise vahel, mis on loomulik dialektiline seaduspärasus.

Klasteranalüüsi tulemused näitavad, et konkreetsema ettekujutuse samatähenduslike sünteetiliste ja analüütiliste verbide tõmbumisest annavad formaalsed tunnused: sõnaliigijärjend ehk struktuur, sagedus ja osakaal. Alamklasside ja klastrite kirjelduse põhjal selgus, et mustri kujunemise oluline formaalne klassifitseeriv tunnus on positsioon (paiknemine verbist vasakul või paremal), mille alusel saab kirjeldada erinevate lekseemide tekstikasutuse semantilisi, struktuurseid ja morfosüntaktilisi piiranguid, leksikaalse ja morfosüntaktilise varieerumise piire ning funktsionaalset potentsiaali. Selles osas annab kolme 
verbipaari klasteranalüüs huvitavaid tulemusi, sest kõrvuti mõningate semantiliste, struktuursete ja morfosüntaktiliste sarnasustega tulevad põhiliselt esile semantilised, struktuursed ja morfosüntaktilised piirangud, mis diferentseerivad sünteetiliste ja analüütiliste verbide kasutust.

Analüüsitud verbipaaridest on otsetähenduses semantiliselt kõige tihedamalt tõmbunud lahkuma ja ära minema (semantilised määrangud 'kuskilt, mingist keskkonnast ära minema' ja 'lahkuma' moodustavad tautoloogilise ringi). Sellega kaasneb struktuurne ja morfosüntaktiline tõmbumine (kasutatud sama morfoloogilist struktuuri VDV, millel kaks mustrit). Seevastu verbid töötama ja tööd tegema tõmbuvad semantiliselt vaid osaliselt, nõustuma ja nõus olema markeerivad erinevaid vaatepunkte. Loomulikult oleks suurema hulga kandidaatpaaride alusel huvitav kontrollida, kas lisaks verbidele lahkuma ja ära minema võib leida teisigi samalaadseid tõmbumise juhtumeid. Samas tõid verbide esinemuse positsioonilised piirangud välja sünteetiliste ja analüütiliste verbide kasutust diferentseerivaid semantilisi, struktuurseid ja morfosüntaktilisi seoseid. Näiteks enamasti paiknevad mustrid verbist vasakul (alamklassid -DV, -SV ja -VV), alamklasside varieerumise avarus/piiratus ja esinemissagedus on pöördvõrdelised: sünteetilistele verbidele on omane avaram varieerumine (kuni viis alamklassi, v.a töötama) ja väiksem sagedus, analüütilisi verbe iseloomustavad üks-kaks alamklassi, mille sagedus ületab kõikide sünteetiliste verbide alamklasside sageduse vähemalt kaks korda. Seega on analüütiliste verbide puhul tegu struktuuride kinnistumisega.

Erinevate verbide klastrikasutuse võrdlus näitab, et sünteetilistel verbidel hakkavad suure hulga klastrite alusel kujunema mustrid, milles esimese (verbilõpulised klastrid) ja viimase komponendi (verbialgulised klastrid) sõnaliik võib vabalt varieeruda või piirdub vaid paari-kolme klastriga. Analüütiliste verbide puhul piirdub muster tavaliselt kahe (harva kolme) klastriga. Seega on analüütiliste verbide kasutuses sagedad struktuurid selgemalt välja joonistunud kui sünteetilistel verbidel (va töötama).

Sünteetiliste ja analüütiliste verbide sagedamate trigrammide võrdluses tulevad esile konkreetsed struktuurid ning nende leksikaalsemantilise ja morfosüntaktilise varieerumise piirid, mis diferentseerivad 
verbide kasutust ja näitavad, et olenemata semantilisest lähedusest on kõikide sünteetiliste ja analüütiliste verbide kasutustingimused nii verbist vasakul kui ka paremal täiesti erinevad. Tegu on kahe erineva verbi sünonüümse varieerumisega üldtähenduses, nt eemaldumine (lahkuma 'kuskilt lahkuma' ja ära minema 'kuskilt ära minema') või tegutsemine (töötama ja tööd tegema 'töötama', 'tööga hõivatud olema'). Tekstikasutuses lisandub täpsustavaid tähendusnüansse, mis hakkavad diferentseerima sünteetilise ning analüütilise verbi semantikat (nt nõustuma - nõus olema üldtähendus 'soostuma' interpreteerituna nõusse jäämise ja nõus olemisena). Kõrvuti tähendusega varieeruvad sünteetilise ja analüütilise verbi struktuursed (sõnaliigijärjendid, sõnajärg) ja morfosüntaktilised (vormid, funktsioonid, predikaadi tüüp) mustrid. Nii on verbipaari töötama - tööd tegema sünonüümne asendamine otsetähenduses ('töötama', 'tööga hõivatud olema') seotud DSV-struktuuri ja modaalpredikaadiga (<on> vaja tööd teha on vaja töötada); verbide lahkuma - ära minema varieerumine otsetähenduses ('kuskilt lahkuma', 'kuskilt ära minema') VDV-struktuuriga, kus mõlemat verbi kasutatakse kas mineviku liitaja vormides või modaalses liitpredikaadis (on juba lahkunud on ära läinud ja tahab ära minna tahab lahkuda) jne. Kõik eespool kirjeldatu näitab, et semantiliselt lähedaste sünteetiliste ja analüütiliste verbide ühendamine on võimalik sõnastikus, kuid tekstikasutusmustrites tuleb enamasti esile nende struktuurne ja morfosüntaktiline diferentseeritus, mis võimaldab neid käsitleda iseseisvate leksikaalsete üksustena. Sõnastike koostamisel tuleks mõelda, kuidas sellega arvestada (seletussõnastikes nt mõistepesade kirjeldamine tüüpiliste kasutuskontekstide alusel, tõlkesõnastikes regulaarsed semantilised ja struktuursed vastavused).

Kõik käesolevas artiklis kirjeldatud piirangud ja piirid, mis samatähenduslike sünteetiliste ning analüütiliste verbide kasutust diferentseerivad, on olulised tasakaalustamaks keele arengus kahte vastandlikku protsessi - vaba varieerumist ja kinnistumist. Klasteranalüüsi tulemused võimaldavad neid reeglistada. Hetkel valdavad samatähenduslikke sünteetilisi ja analüütilisi verbe eristavad grammatilised jooned, kuid mustrite hulk, morfosüntaktilise varieerumise avarus, sünonüümsed 
asendused, samuti sünteetiliste ning analüütiliste verbide tõmbumisega seotud semantilise, struktuurse ja morfosüntaktilise eristuse neutraliseerumise juhtumid viitavad kasutusreeglite ebakindlusele.

\section{Lühendid}

S substantiiv

A adjektiiv

$\mathrm{N}$ numeraal

$\mathrm{P}$ pronoomen

$\mathrm{V} \quad$ verb

D adverb

K adpositsioon

J konjunktsioon

G genitiivatribuut

\section{Kirjandus}

Aikhenvald, Alexandra Y. 2007. Grammars in contact: A cross-linguistic perspective. - Grammars in Contact: A Cross-Linguistic Typology. Explorations in Linguistic Typology 4. Oxford: Oxford University Press, 1-66.

Asser, Hiie, Heiki-Jaan Kaalep, Siret Linnas, Jaan Mikk, Kadri Muischnek, Merje Songe, Heli Uibo 2004. Õpikute keerukuse analüüs arvutitel. ['Automatic complexity analysis of textbooks'.] - Maria-Maren Sepper, Jane Lepasaar, Helle Metslang (Toim.). Toimiv keel II. Töid rakenduslingvistika alalt. Tallinn: TPÜ Kirjastus, 72-84.

Bybee, Joan L., Clay Beckner 2010. Usage-Based Theory. https://www.unm. edu/ jbybee/downloads/BybeeBeckner2010UsageBasedTheory.pdf (23.4.2015).

Croft, William D., Alan Cruse 2004. Cognitive Linguistics. New York: Cambridge University Press.

Demidova jt 1986 = А. К. Демидова, Х. Буттке, К. Буттке. Русско-немецкие эквиваленты глагольно-именных сочетаний. Verbale Wortfügungen mit nominaler Komponente im Russischen und Deutschen. Москва: Высшая Школа.

Dixon, Robert M. W., Aleksandra Y. Aikhenvald 2002. Word. A Cross-Linguistic Typology. New York: Cambridge University Press. 
EKSS = Eesti keele seletav sõnaraamat. Margit Langemets, Mai Tiits, Tiia Valdre, Leidi Veskis, Ülle Viks, Piret Voll (Toim.). Tallinn: Eesti Keele Sihtasutus, 2009. http://www.eki.ee/dict/ekss/

Eslon, Pille 2004. Mõningatest korrelatsioonidest vene ja eesti verbisüsteemis. ['Some correlations in Russian and Estonian verb system'.] - MariaMaren Sepper, Jane Lepasaar, Helle Metslang (Toim.). Toimiv keel II. Töid rakenduslingvistika alalt. Tallinn: TPÜ Kirjastus, 103-122.

Eslon, Pille 2005. Deiktikud ja aspektisituatsioonid. ['Deictics and aspectual situations.] http://evkk.tlu.ee/wwwdata/studiaIVb_ESLON_363-381.pdf(9.4.2015).

Eslon, Pille 2010. Muutustest eesti keele grammatiliste käänete kasutamisel. ['Changes in the use of Estonian grammatical cases.'] - Lähivõrdlusi. Lähivertailuja 19, 38-60. http://dx.doi.org/10.5128/LV19.03

Eslon, Pille 2014a. Adverbi sisaldavate struktuuride tekstifunktsioonidest eesti ilukirjandus- ja õppijakeeles. ['On the textual functions of adverbial structures in literary Estonian and in Estonian learner language'.] - Lähivõrdlusi. Lähivertailuja 24, 15-46. http://dx.doi.org/10.5128/LV24.01

Eslon, Pille 2014b. Morfosüntaktilise ja leksikaalse varieerumise piiridest: ilukirjandus- ja õppijakeele kasutusmustrite võrdlus. ['Constraints on morphosyntactic and lexical variability'.] - Eesti Rakenduslingvistika Ühingu aastaraamat 10, 55-71. http://dx.doi.org/10.5128/ERYa10.04

Grünthal, Riho 2010. Sijasynkretismi morfologian koetinkivenä. ['The role of syncretism in the morphology of he Finnic languages.] - ESUKA - JEFUL 1 (2), 91-113.

Grünthal, Riho 2003. Finnic Adpositions and Cases in Change. Suomalais-Ugrilaisen Seuran toimituksia 244. Helsinki: Finno-Ugrian Society.

Haspelmath, Martin 2010. The indeterminacy of word segmentation and the nature of morphology and syntax. http://www.academia.edu/237883/ The_indeterminacy_of_word_segmentation_and_the_nature_of_morphology_and_syntax (22.4.2015).

Haspelmath, Martin 1999. Optimality and diachronic adaptation. - Zeitschrift für Sprachwissenschaft 18 (2), 180-205. http://dx.doi.org/10.1515/ zfsw. 1999.18.2.180

Haspelmath, Martin 2007. Creating economical morphosyntactic patterns in language change. - Jeff Good (Ed.). Language Universals and Language Change. Oxford: Oxford University Press. http://email.eva.mpg. de/ haspelmt/CreatingEconomy.pdf (10.4.2015).

Heine, Bernd, Tania Kuteva 2007. The Genesis of Grammar. A Reconstruction. New York: Oxford University Press. 
Kant, Immanuel 1904. Kritik der reinen Vernunft. Königlich Preussischen Akademie der Wissenschaften. Berlin: Reimer.

Larjavaara, Matti 1991. Aspektuaalisen objektin synty. ['The origin of the aspectual object'.] - Virittäjä 95 (4), 372-408.

Muischnek, Kadri, Kadri Vider 2005. Sõnaliigituse kitsaskohad eesti keele arvutianalüüsis. ['The problems of word class disambiguation in the automatic analysis of Estonian.] - Eesti Rakenduslingvistika Ühingu aastaraamat 1, 99-114. http://dx.doi.org/10.5128/ERYa1.05

Paeoja, Heleriin 2011. Keeltevahelistest seostest ja analoogselt kulgevatest protsessidest. Seminaritöö. Tallinna Ülikool.

Paeoja, Heleriin 2012. Analüütiliste ja sünteetiliste verbipaaride kasutamise võrdlus 1890ndate ja 1990ndate ajakirjanduskeeles. Bakalaureusetöö. Tallinna Ülikool.

Paeoja, Heleriin 2015. Analüütiliste / sünteetiliste verbipaaride kasutusmustrid 1990ndate aastate eesti ilukirjanduskeeles. Magistritöö. Tallinna Ülikool.

Pajusalu, Renate 1999. Deiktikud eesti keeles. Dissertationes philologiae Estonicae Universitatis Tartuensis 8. Tartu: Tartu Ülikool.

Ots, Sander 2012. Statistikapõhise tarkvara loomine morfoloogiliste kollokatsioonide eraldamiseks eesti keele tekstidest. ['Software for Morphosyntactic Cluster Extraction from Estonian Texts.'] Bakalaureustöö. Tallinna Ülikool.

TEA 2001 = Vene-eesti seletav sõnaraamat eesti-vene sõnastikuga. ['Russian-Estonian explanatory dictionary with Estonian-Russian dictionary'.] Tallinn: TEA.

TEA 2005 = Eesti-vene sõnaraamat. ['Estonian-Russian dictionary'.] Tallinn: TEA. TEA 2007 = TEA koolisõnastik. Vene-eesti. ['TEA school dictionary: RussianEstonian'] Tallinn: TEA.

TEA, 2010 = TEA koolisõnastik. Eesti-vene. ['TEA school dictionary: EstonianRussian'.] Tallinn: TEA.

Trainis, Jekaterina 2015. Linguistic cluster analysis: A method for describing language units and indicating regularities in language. - Within Language, Beyond Theories. Vol. III. Discourse Analysis, Pragmatics and Corpusbased Studies. Cambridge Scholars Publishing.

Trainis, Jekaterina, Kais Allkivi 2014. Ilukirjanduskeelest uue pilguga. ['On belletristic language from a new perspective..] - Eesti Rakenduslingvistika Ühingu aastaraamat 10, 283-306. http://dx.doi.org/10.5128/ERYa10.18

Vaiss, Natalia 2004. Eesti keele aspekti väljendusvõimalusi vene keele taustal. ['The Expression of Aspect in Estonian in Comparison with Russian'.] Magistritöö. Tallinna Ülikool. http://hdl.handle.net/10062/44143 


\title{
Use of the synonymous synthetic and analytic verbs
}

\author{
PILLE ESLON, HELERIIN PAEOJA \\ Tallinn University
}

The first author of this paper developed an interest in synonymous synthetic and analytic verbs while editing Russian-Estonian-Russian translation dictionaries, upon discovering regularities in the relationships between aspect in Russian verbs and the choice between synthetic and analytic Estonian verbs as translation equivalents.

While this phenomenon is rare and difficult to notice, it nevertheless raises questions: when do native speakers prefer to use synthetic and analytic verbs, respectively? In addition to synonymy and simplicity of form (synthetic verbs have only one component, while analytic verbs have at least two), are there other features that affect the choice of synthetic or analytic verbs? The present study aims to answer these questions.

Five pairs of synonymous synthetic and analytic verbs are analyzed: igatsema - igatsust tundma 'to long for, miss', lahkuma - ära minema 'to leave', nõustuma - nõus olema 'to agree', muretsema - muret tundma 'to be worried', töötama - tööd tegema 'to work'. We look for linguistic structures characteristic of both members of the given pairs, analyze the limits of their lexico-semantic and morphosyntactic variation, and compare the verbs' meanings. On the basis of these features, it is possible to determine whether the pairs consist of two distinct verbs or two forms of the same verb. The theoretical-empirical aspect of the study is connected to the hypothesis of contraction of synonymous synthetic and analytic verbs, according to which semantically related synthetic-analytic verb pairs emerge, wherein the synthetic verb is used to denote abstract (indefinite) actions and the analytic verb is used for concrete (definite) actions. This process is accompanied by structural, morphological, morphosyntactic and lexico-semantic limitations on the usage of the verbs in question. The contraction of synonymous synthetic and analytic verbs is a process that takes place on the lexico-grammatical periphery. These verbs contribute to general linguistic variation, but in addition, a number of lexico-semantic, grammatical and structural 
restrictions develop on the usage of these verbs. Opposite tendencies - petrification and variation - work toward the same goal.

Keywords: synthetic and analytical verbs; usage grammar; morphological structures; morphosyntactical patterns; lexico-semantical and grammatical variability; cluster analysis; n-grams; Estonian

\section{Pille Eslon}

Tallinna Ülikooli digitehnoloogiate instituut Narva mnt 2510120 Tallinn, Estonia

vanemteadur

peslon@tlu.ee

\section{Heleriin Paeoja}

Tallinna Ülikooli haridusteaduste instituut Narva mnt 2510120 Tallinn, Estonia

magistrant

helluhe@tlu.ee 